



\section{Onderbouwing DGF-plafonds 2020/2024}

M.A.P.M. Van Asseldonk' ${ }^{1}$, A.R.W. Elbers ${ }^{2}$, T.J. Hagenaars ${ }^{2}$, G.J. Boender ${ }^{2}$, R.H.M. Bergevoet ${ }^{1}$

1 Wageningen Economic Research

2 Wageningen Bioveterinary Research

Dit onderzoek is uitgevoerd door Wageningen Economic Research en Wageningen Bioveterinary Research in opdracht van en gefinancierd door het ministerie van Landbouw, Natuur en Voedselkwaliteit, in het kader van het Beleidsondersteunend onderzoeksthema 'Agro-economie, markt en handel' (projectnummer BO-43-014.01)

Wageningen University \& Research

Wageningen, mei 2019

RAPPORT

2019-046

ISBN 978-94-6343-965-7 
Van Asseldonk, M.A.P.M., Elbers, A., Hagenaars, T., Boender, G.J., Bergevoet, R., 2019. Onderbouwing DGF-plafonds 2020/2024. Wageningen, Wageningen Economic Research, Rapport 2019-046. 42 blz.; 5 fig.; 16 tab.; 11 ref.

De berekende verwachte DGF-bijdrage in de bestrijdingskosten voor mond-en-klauwzeer (MKZ) en klassieke varkenspest (KVP), rekening houdend met een EU-bijdrage, is in de 2020/2024-scenario's lager dan eerder berekend voor de periode 2015/2019. De gemiddelde DGF-bijdrage in de varkenshouderij voor MKZ en KVP wordt geschat op 3,12 mln. euro per 5 jaar in plaats van $13 \mathrm{mln}$. euro per 5 jaar. In de rundveehouderij zijn de gemiddelde bestrijdingskosten voor MKZ afgenomen van $9 \mathrm{mln}$. euro naar 2,89 mln. euro per 5 jaar. Voor de schapen- en geitenhouderij is dit 0,15 mln. euro per 5 jaar (was 0,49 $\mathrm{mln}$. euro). In de pluimveehouderij is de DGF-bijdrage in de bestrijdingskosten voor aviaire influenza (AI) min of meer gelijk gebleven (36 mln. euro per 5 jaar), waarbij de kans op AI-insleep juist is toegenomen maar de omvang van een AI-uitbraak aanzienlijk minder is.

Trefwoorden: Diergezondheidsfonds, mond-en-klauwzeer (MKZ), klassieke varkenspest (KVP) en aviaire influenza $(\mathrm{AI})$

Dit rapport is gratis te downloaden op https://doi.org/10.18174/476589 of op www.wur.nl/economicresearch (onder Wageningen Economic Research publicaties).

(C) 2019 Wageningen Economic Research

Postbus 29703, 2502 LS Den Haag, T 07033583 30, E communications.ssg@wur.nl, www.wur.nl/economic-research. Wageningen Economic Research is onderdeel van Wageningen University \& Research.

\section{(cc) BY-NC}

Dit werk valt onder een Creative Commons Naamsvermelding-Niet Commercieel 4.0 Internationaallicentie.

(C) Wageningen Economic Research, onderdeel van Stichting Wageningen Research, 2019 De gebruiker mag het werk kopiëren, verspreiden en doorgeven en afgeleide werken maken. Materiaal van derden waarvan in het werk gebruik is gemaakt en waarop intellectuele eigendomsrechten berusten, mogen niet zonder voorafgaande toestemming van derden gebruikt worden. De gebruiker dient bij het werk de door de maker of de licentiegever aangegeven naam te vermelden, maar niet zodanig dat de indruk gewekt wordt dat zij daarmee instemmen met het werk van de gebruiker of het gebruik van het werk. De gebruiker mag het werk niet voor commerciële doeleinden gebruiken.

Wageningen Economic Research aanvaardt geen aansprakelijkheid voor eventuele schade voortvloeiend uit het gebruik van de resultaten van dit onderzoek of de toepassing van de adviezen.

Wageningen Economic Research is ISO 9001:2008 gecertificeerd.

Wageningen Economic Research Rapport 2019-046 | Projectcode 2282300343

Foto omslag: Bram Belloni/Hollandse Hoogte 


\section{Inhoud}

Woord vooraf $\quad 5$

$\begin{array}{ll}\text { Samenvatting } & 6\end{array}$

$\begin{array}{ll}1 & \text { Inleiding }\end{array}$

$\begin{array}{lll}1.1 & \text { Probleemstelling } & 7\end{array}$

$\begin{array}{lll}1.2 & \text { Onderzoeksvraag } & 7\end{array}$

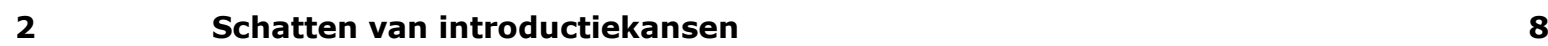

2.1 Aanpak inschatten introductiekansen $\quad 8$

2.2 Klassieke Varkenspest (KVP) $\quad 8$

2.3 Afrikaanse Varkenspest (AVP) 9

2.4 Mond-en-klauwzeer (MKZ) 12

2.5 Hoog-pathogene aviaire influenza (HPAI) 14

$\begin{array}{llr}2.6 & \text { Rundertuberculose } & 19\end{array}$

3.1 Aanpak modellering van transmissie $\quad 20$

3.2 Resultaten modellering van transmissie $\quad 22$

3.2.1 Omvang uitbraken KVP $\quad 22$

$\begin{array}{ll}3.2 .2 \text { Omvang uitbraken MKZ } & 23\end{array}$

3.2.3 Omvang uitbraken HPAI 23

$4 \quad$ Economische gevolgen $r 25$

4.1 Aanpak berekeningen economische gevolgen 25

4.2 Uitgangspunten bestrijdingskosten inclusief organisatiekosten 25

4.3 Verwachte kosten van besmettelijke dierziektenuitbraken 27

$\begin{array}{lll}4.4 & \text { Kansverdeling van schadebedragen } & 27\end{array}$

4.4.1 Varkenshouderij 28

4.4.2 Rundveehouderij 29

4.4.3 Schapen- en geitenhouderij $\quad 32$

$\begin{array}{ll}\text { 4.4.4 Pluimveehouderij } & 32\end{array}$

$\begin{array}{ll}\text { Literatuur en websites } & \mathbf{3 7}\end{array}$

Bijlage 1 Uitsplitsing schade schapenhouderij en geitenhouderij 38

Bijlage 2 Relatie plafondbedrag en overheidsbijdrage in de schapenhouderij en geitenhouderij 



\section{Woord vooraf}

In de Gezondheids- en welzijnswet voor dieren (Gwwd) is bepaald dat iedere vijf jaar nieuwe convenantafspraken gemaakt moeten worden tussen overheid en veehouderijsectoren over de verdeling van de kosten die de overheid moet maken voor het handhaven van de diergezondheid. Per 2020 start een nieuwe convenantperiode. Om deze afspraken te ondersteunen hebben Wageningen Economic Research en Wageningen Bioveterinary Research een analyse uitgevoerd inzake de kans op introductie en de verwachte gevolgen van mogelijke uitbraken van bestrijdingsplichtige dierziekten. De uitkomsten van deze analyse kunnen mede als basis gebruikt worden voor een nieuw te sluiten diergezondheidsfonds (DGF) convenant. Momenteel starten namelijk de onderhandelingen over de herijking van het convenant 'Financiering bestrijding besmettelijke dierziekten/DGF'. Daarbij zijn afspraken over de hoogte van de 'plafondbedragen' een van de belangrijkste aandachtspunten.

Het onderzoek is gefinancierd door het ministerie van LNV. Behalve aan de contactpersoon Pascalle de Ruyter is ook veel dank verschuldigd aan RVO.nl, voor het ter beschikking stellen van de overzichten met DGF uitgaven, het deskundigenpanel bestaande uit Mart de Jong, Arjan Stegeman en Ruth Bouwstra, en aan de deskundigen vanuit de sectoren die hun ervaringen en inzichten over dit onderwerp hebben willen delen.

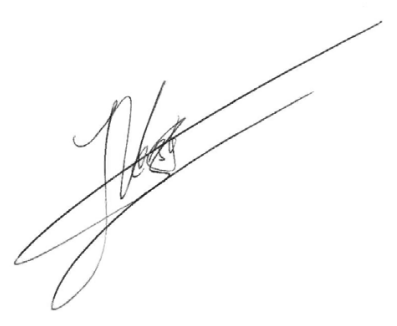

Prof.dr.ir. J.G.A.J. (Jack) van der Vorst

Algemeen Directeur Social Sciences Group (SSG)

Wageningen University \& Research 


\section{Samenvatting}

\section{Achtergrond}

Binnen het Diergezondheidsfonds (DGF) is de verdeling van kosten tussen bedrijfsleven en overheid voor bestrijdingsactiviteiten geregeld door middel van convenanten per veehouderijsector. Onderdeel van de regeling zijn de plafondbedragen; het maximumbedrag dat iedere sector zelf moet dragen bij een uitbraak van een besmettelijke dierziekte. Deze plafondbedragen worden aan het begin van de convenantperiode voor de duur van vijf jaar per sector in overleg tussen bedrijfsleven en overheid vastgesteld. Per 2020 start een nieuwe convenantperiode (2020-2024).

De omstandigheden waarin de veehouderij functioneert zijn aan verandering onderhevig. Zo neemt het aantal bedrijven af, dienen zich nieuwe bestrijdingsmethoden aan, veranderen de handelscontacten en is er voortschrijdend wetenschappelijk inzicht. Hierdoor veranderen de aannames voor de berekeningen waarop de plafonds mede zijn gebaseerd. De in dit rapport uitgevoerde berekeningen kunnen een ondersteuning bieden bij de besluitvorming over een eventuele bijstelling van de plafondbedragen door de convenantpartijen in het DGF.

Uitbraken van zeer besmettelijke dierziekten als mond- en klauwzeer (MKZ), klassieke varkenspest (KVP) en aviaire influenza ( $\mathrm{AI}$ ) kunnen grote (financiële) gevolgen hebben en daarmee een grote aanslag doen op de middelen van het DGF. Onderzoek naar de directe bestrijdingskosten gerelateerd aan deze ziekten is belangrijk voor het vaststellen van de verwachte schade voor de komende convenantperiode. Daarom is de mogelijke schadeomvang van uitbraken in verschillende sectoren geanalyseerd met behulp van simulatiemodellen.

\section{Resultaten}

De introductiekansen van MKZ en KVP zijn beide verlaagd ten opzichte van de vorige convenantperiode (2015-2019) naar 1 keer per 15 jaar. Voor de komende convenantperiode wordt de kans op een HPAI seizoen van hoog-pathogene AI (HPAI) geschat op gemiddeld 0,75 per jaar (3 uit 4 seizoenen) en gemiddeld 5,33 uitbraken per HPAI-seizoen (16 afzonderlijke/onafhankelijke uitbraken in 3 seizoenen).

De verwachte MKZ- en KVP-uitbraakomvang zijn vergelijkbaar met de eerdere resultaten uit het rapport voor de convenantperiode 2015-2019. Voor HPAI is de voorspelde omvang van epidemieën beperkter.

De verwachte DGF-bijdrage in de bestrijdingskosten voor MKZ en KVP, rekening houdend met een EUbijdrage, is in de 2020/2024-scenario's lager dan eerder berekend voor de periode 2015/2019. De gemiddelde DGF-bijdrage in de varkenshouderij voor MKZ en KVP wordt geschat op 3,12 mln. euro per vijf jaar in plaats van $13 \mathrm{mln}$. euro per vijf jaar in de vorige convenantperiode. In de rundveehouderij zijn de gemiddelde bestrijdingskosten voor MKZ afgenomen van 9 mln. euro naar 2,89 mln. euro per vijf jaar. Voor de schapen- en geitenhouderij is dit 0,15 mln. euro per vijf jaar (was 0,49 $\mathrm{mln}$. euro). In de pluimveehouderij zijn de verwachte bestrijdingskosten voor AI min of meer gelijk gebleven (36 mln. euro per vijf jaar), waarbij de kans op AI-insleep juist is toegenomen maar de omvang van een AI-uitbraak aanzienlijk minder is. 


\section{$1 \quad$ Inleiding}

\section{$1.1 \quad$ Probleemstelling}

In de Gezondheids- en welzijnswet voor dieren (Gwwd) is bepaald dat iedere vijf jaar nieuwe convenantafspraken gemaakt moeten worden tussen overheid en veehouderijsectoren over de verdeling van de kosten die de overheid moet maken voor het handhaven van de diergezondheid. Per 2020 start een nieuwe convenantperiode. Om deze afspraken te ondersteunen hebben Wageningen Economic Research en Wageningen Bioveterinary Research een analyse uitgevoerd inzake de kans op introductie en de verwachte gevolgen van mogelijke uitbraken van bestrijdingsplichtige dierziekten.

De uitkomsten van deze analyse kunnen mede als basis gebruikt worden voor een nieuw te sluiten diergezondheidsfonds (DGF) convenant. Momenteel starten namelijk de onderhandelingen over de herijking van het convenant 'Financiering bestrijding besmettelijke dierziekten/DGF' voor de periode 2020-2024. Daarbij zijn afspraken over de hoogte van de 'plafondbedragen' een belangrijk aandachtspunt. Het plafondbedrag is het maximumbedrag dat iedere sector zelf moet dragen bij een uitbraak van een besmettelijke dierziekte. Kosten die hoger zijn dan deze plafondbedragen worden door de overheid (ministerie van LNV) gedragen. Deze plafondbedragen worden aan het begin van de convenantperiode per sector voor de duur van vijf jaar per sector in overleg tussen bedrijfsleven en overheid vastgesteld. Voor een nieuw convenant DGF is draagvlak noodzakelijk en dat begint met afspraken over plafondbedragen. Wetenschappelijke uitgangspunten zijn daarbij de basis.

De uitgaven van het DGF hebben betrekking op kosten die gemaakt worden voor:

a. De bestrijding van de dierziektes die opgenomen zijn in de Gezondheids- en welzijnswet voor dieren;

b. Preventieve maatregelen die de kans op een uitbraak van besmettelijke dierziektes verkleinen;

c. Overname en onderzoek van dieren die worden verdacht van een besmettelijke dierziekte;

d. Eventuele schadeloosstelling na ruiming van dieren op besmette bedrijven;

e. Monitoring en screening.

Zijn de verwachte uitgaven van de onderdelen b. tot en met e. redelijk goed van te voren in te schatten, de kosten verbonden aan de bestrijding van de dierziektes zijn moeilijk in te schatten. Met name de uitgaven in verband met ('incidentele') uitbraken van een van de zeer besmettelijke dierziekten (mond- en klauwzeer (MKZ), klassieke varkenspest (KVP) en aviaire influenza (AI)) kunnen fors oplopen.

\subsection{Onderzoeksvraag}

Om inzicht te krijgen in de verwachte kosten is Wageningen Economic Research en Wageningen Bioveterinary Research gevraagd om hiervoor aanvullend onderzoek te doen. Doel van het huidige onderzoek is het inschatten van de kansverdeling van de schadelast van MKZ, KVP en AI ter ondersteuning van het bepalen van de nieuwe DGF-plafondbedragen voor de sectoren rundveehouderij, varkenshouderij, schapen- en geitenhouderij en pluimveehouderij. Hiervoor is gekozen voor een aanpak vergelijkbaar aan de onderzoeken uitgevoerd voor de voorgaande convenantonderhandelingen (Van Asseldonk et al., 2009; Van Asseldonk et al., 2014). De inschatting wordt waar mogelijk onderbouwd door wetenschappelijk onderzoek naar de kans op introductie van (een van) deze dierziekten (naast MKZ, KVP en AI ook Afrikaanse varkenspest en rundertuberculose) (Hoofdstuk 2) en de verspreiding van MKZ, KVP en AI (Hoofdstuk 3). In Hoofstuk 4 volgen de directe bestrijdingskosten over de voorliggende convenantperiode ingeschat. 


\section{Schatten van introductiekansen}

\subsection{Aanpak inschatten introductiekansen}

Voor het inschatten van de introductiekansen is het aantal introducties voor de betreffende dierziekte in Nederland en omliggende landen geanalyseerd. Daarnaast zijn ook de importstromen van dieren geïnventariseerd. Dit zijn de meest objectieve gegevens waarop wij onze inschatting van de introductiekansen kunnen baseren. Vervolgens zijn de inschattingen voorgelegd aan een deskundigenpanel.

\section{$2.2 \quad$ Klassieke Varkenspest (KVP)}

Huidige situatie Nederland

Sinds het ingaan van het Europese non-vaccinatiebeleid voor KVP (1989) heeft in Nederland in totaal drie keer een introductie van KVP plaatsgevonden (in 1990, 1992, en 1997). Dit levert een initiële KVP-introductiekans op van 3 per 29 jaar, oftewel 1 keer per 10 jaar. Nederland is echter al weer 20 jaar KVP-vrij.

\section{Situatie in Europa}

In België en Duitsland is de situatie bij de wilde zwijnen zeer sterk verbeterd (middels orale vaccinatie); de laatste uitbraak in wilde zwijnen is negen jaar geleden (2009). Hierdoor is er een KVPvrije buffer ontstaan, waar Nederland mede van profiteert.

In de rest van Europa:

- Letland: uitbraken in 2012, 2013, 2014, 2015

- Litouwen: uitbraken in 2009, 2011

- Ukraine: uitbraken in 2014

- Servië: uitbraken in 2007, 2010, 2011

- Rusland: uitbraken in 2005 tot en met 2018.

Hoewel niet officieel bekend, zou in Roemenië en Bulgarije nog KVP aanwezig kunnen zijn in wilde zwijnen en backyard varkens. Dit kan belangrijk zijn omdat in de Nederlandse varkenshouderij personeel zou kunnen worden ingezet uit Roemenië en Bulgarije.

In tabel 2.1 is de import van gedomesticeerde varkens vanuit Europese landen van de afgelopen drie jaren weergegeven (bron: CBS Statline). Er zijn de afgelopen drie jaar geen of heel weinig gedomesticeerde varkens in Nederland geïmporteerd uit landen waar KVP heerst of vermoed wordt te heersen. Aan de andere kant wordt waarschijnlijk personeel ingezet op Nederlandse varkensbedrijven uit Oost-Europese landen waar KVP mogelijk heerst bij wilde zwijnen en backyard varkens of uit naburige landen geïntroduceerd kan worden (Bulgarije en Roemenië). 
Tabel 2.1 Import van gedomesticeerde varkens uit Europese landen in de periode 2015-2017

\begin{tabular}{|c|c|c|c|}
\hline \multirow[b]{2}{*}{ Land } & \multicolumn{3}{|c|}{ Import varkens vanuit Europese landen } \\
\hline & 2015 & 2016 & 2017 \\
\hline België & 645.133 & 961.902 & 976.428 \\
\hline Bulgarije & 187 & 447 & 384 \\
\hline Cyprus & 15 & 22 & 59 \\
\hline Denemarken & 74.577 & 171.246 & 276.176 \\
\hline Duitsland & 518.414 & 464.788 & 361.966 \\
\hline Estland & 988 & 1.675 & 1.258 \\
\hline Finland & 682 & 1.230 & 1.433 \\
\hline Frankrijk & 30.184 & 40.761 & 53.827 \\
\hline Griekenland & 167 & 670 & 486 \\
\hline Hongarije & 16.267 & 46.256 & 81.815 \\
\hline Ierland & 3.437 & 5.421 & 7.933 \\
\hline Italië & 13.569 & 18.831 & 16.174 \\
\hline Kroatië & 11.497 & 27.109 & 43.062 \\
\hline Letland & 169 & 6.430 & 1.060 \\
\hline Litouwen & 393 & 839 & 726 \\
\hline Luxemburg & 236 & 4.736 & 6.468 \\
\hline Malta & 14 & 25 & 23 \\
\hline Noorwegen & 356 & 487 & 394 \\
\hline Oostenrijk & 893 & 10.581 & 9.289 \\
\hline Polen & 7.246 & 11.109 & 63.857 \\
\hline Portugal & 1.503 & 1.494 & 1.466 \\
\hline Roemenië & 304 & 4.787 & 1.336 \\
\hline Slovenië & 995 & 914 & 424 \\
\hline Slowakije & 2014 & 7.027 & 1.855 \\
\hline Spanje & 14.894 & 24.392 & 9.993 \\
\hline Tsjechië & 4.227 & 18.463 & 10.966 \\
\hline Verenigd Koninkrijk & 8.215 & 13.090 & 14.175 \\
\hline Zweden & 1.636 & 2.747 & 3.261 \\
\hline
\end{tabular}

Bron: CBS Statline.

Conclusie introductiekans KVP

Nederland is al weer 20 jaar KVP-vrij. In België en Duitsland is de situatie bij de wilde zwijnen zeer sterk verbeterd waardoor er een KVP-vrije buffer is ontstaan. Er worden heel weinig tot geen varkens aangeleverd uit landen waar KVP heerst. Aan de andere kant wordt waarschijnlijk personeel ingezet op Nederlandse varkensbedrijven uit Oost-Europese landen waar KVP mogelijk heerst of uit naburige landen geïntroduceerd kan worden. De schatting voor de introductiekans voor KVP in vergelijking met de vorige convenantperiode wordt verlaagd naar 1 keer per 15 jaar (was 1 per 10 jaar).

\subsection{Afrikaanse Varkenspest (AVP)}

\section{Introductie $^{1}$}

Afrikaanse varkenspest komt voornamelijk voor in Afrika, meer specifiek in de landen ten zuiden van de Sahara. Buiten Afrika werd de ziekte voor het eerst gesignaleerd in Portugal, in 1957. Vanaf 1960 verspreidde de ziekte zich naar Spanje en in latere jaren waren er uitbraken in onder andere Frankrijk, Italië, Malta, België en Nederland. Midden jaren negentig was het virus overal buiten Afrika weer uitgeroeid, met uitzondering van het Italiaanse eiland Sardinië. Daar komt de ziekte tot op de dag van vandaag voor.

In 2007 dook het virus vervolgens op in Georgië, in de Kaukasus. Van daaruit heeft het virus zich verspreid naar landen als Armenië en Azerbeidzjan, en uiteindelijk ook naar Rusland. In de jaren

1 Gebaseerd op Loeffen, 2018 (Risicoanalyse voor introductie van Afrikaanse varkenspest in gehouden varkens en wilde zwijnen in Nederland. WBVR Rapport aug. 2018 in opdracht van ministerie van LNV). 
daarna verspreidde het virus zich over vrijwel geheel West-Rusland, met uitbraken tot aan de grens met Finland. In 2012 werd ook een uitbraak vastgesteld in Oekraïne, in 2013 gevolgd door Wit-

Rusland. In 2014 werden de eerste introducties in de Europese Unie waargenomen toen kort achter elkaar besmette wilde zwijnen in Litouwen en Polen werden gevonden. Kort daarna verspreidde het virus zich ook naar Letland en Estland. In 2016 verspreidde het zich naar Moldavië en in 2017 naar Tsjechië en Roemenië. In 2018 werden de eerste uitbraken in Hongarije gemeld. In augustus 2018 werd voor het eerst melding gemaakt van een uitbraak in China. De recente vondst (13-16 september 2018) van besmette wilde zwijnen in Zuid-België laat zien dat het infectiereservoir in wilde zwijnen zich nu ook tot in West-Europa uitstrekt. Het besmette gebied is sinds 2007 enorm gegroeid. Binnen de EU verloopt de uitbreiding van besmette gebieden vooralsnog langzamer dan voorheen in de Kaukasus en Rusland.

\section{Situatie wereldwijd}

In Afrika, meer speciaal ten zuiden van de Sahara, is de ziekte endemisch. Hier is sprake van een sylvatische cyclus tussen wrattenzwijnen (van het geslacht Phacochoerus) en zachte teken (Ornithodoros moubata). Vanuit deze cyclus kunnen andere wilde varkensachtigen besmet worden, waaronder ook gehouden varkens. Daarnaast speelt ook de directe verspreiding tussen gehouden varkens een belangrijke rol, veelal via vlees, vleesproducten en slachtafval.

In het Aziatische deel van Rusland zijn in 2017 ook diverse infectiehaarden gemeld, tot de regio noordelijk van Mongolië. Hier is verspreiding over grote afstanden geweest. Vooralsnog zijn dit incidentele uitbraken die niet hebben geleid tot ongecontroleerde lokale verspreiding en het endemisch worden van AVP in de betreffende regio's. In augustus 2018 werd voor het eerst melding gemaakt van Afrikaanse varkenspest in het Noordoosten van China, op circa $150 \mathrm{~km}$ van de Noord-Koreaanse grens. Ondertussen (d.d. 18 Sept. 2018) zijn er 22 uitbraken geteld in 7 verschillende provincies (die ver uit elkaar liggen).

\section{Situatie Europa}

In de afgelopen maanden bleef het virus onverminderd actief in Oost-Europa en Rusland. In Polen is het getroffen gebied in omvang toegenomen. Behalve in de oostelijke grensstreek is het virus inmiddels actief in de buurt van Warschau en langs de noordgrens met Rusland (Kaliningrad). In Tsjechië lijkt de uitbraak bij wilde zwijnen onder controle te zijn en lijkt het gelukt om het virus ter plaatse uit te roeien. Roemenië heeft te maken gekregen met nieuwe introducties langs de noordgrens met Oekraïne, gevolgd door een explosieve toename van het aantal besmette gehouden varkens in het oosten, eveneens in de grensstreek met Oekraïne. Op 20 april 2018 meldde Hongarije de eerste uitbraken bij wilde zwijnen. Behalve een geïsoleerde haard in het midden van het land, waren er later ook uitbraken langs de grens met Oekraïne.

Estland, Litouwen en Italië (Sardinië) melden geen individuele uitbraken meer aan de OIE, maar ook daar is het virus actief. Binnen de EU circuleerde het virus in het begin van het jaar vooral onder wilde zwijnen, terwijl in Oekraïne de uitbraken zich vooral bij de gehouden varkens lijken af te spelen, of althans daar vooral gedetecteerd worden. In de afgelopen 3 maanden hebben zich echter ook in veel Europese landen weer veel uitbraken bij gehouden varkens voorgedaan.

\section{Europa - gedomesticeerde varkens}

In 2017 zijn vooral in Polen en Oekraïne, gevolgd door Litouwen, relatief veel gevallen geweest bij gehouden varkens. Dit beeld zet zich in 2018 voort. Sinds de introductie van AVP in het oosten van Roemenië (10 juni 2018) is het aantal besmette varkenshouderijen daar explosief toegenomen. Het betreft hier voornamelijk backyard holdings, met inmiddels meer dan 500 uitbraken (ADNS-data). Daarnaast zijn er ook 2 grote commerciële bedrijven (die onderling contact hadden) besmet geraakt.

\section{Europa - wilde zwijnen}

Het merendeel van de uitbraken speelt zich in de meeste landen af bij de wilde zwijnen. Ook hier is er in de loop der jaren eerder een stijgende dan een dalende trend. Vooral in Polen worden nog steeds veel uitbraken gedetecteerd in wilde zwijnen. Ook in de Baltische staten is er nog geen echte afname. In Roemenië speelt de verspreiding van het virus zich nog voornamelijk in gehouden varkens af, met een relatief gering aantal vastgestelde uitbraken bij wilde zwijnen. Ook in Oekraïne worden relatief 
weinig besmettingen waargenomen bij wilde zwijnen, ten opzichte van de gehouden varkens. Of hier een onderrapportage is of een andere epidemiologie, meer gericht op verspreiding tussen kleinschalige bedrijven onderling, is niet zeker. De meest recente vondst (13-16 september 2018) van besmette wilde zwijnen in Zuid-België laat zien dat het infectiereservoir in wilde zwijnen zich nu ook tot in WestEuropa uitstrekt. Deze vondst in het uiterste Zuidoosten van België (provincie Luxembourg) betrof verschillende dode wilde zwijnen waarbij in monstermateriaal positieve PCR resultaten zijn gevonden met betrekking tot ASF-virus.

\section{Huidige situatie Nederland}

In Nederland heeft zich in het verleden één keer eerder een uitbraak van AVP voorgedaan. Dat was in 1986, waarbij 2 bedrijven in Zuid-Holland besmet zijn geraakt. Deze uitbraak was indirect gelinkt aan de situatie op het Iberische schiereiland, waar van circa 1960 tot 1995 Afrikaanse varkenspest endemisch was. In Nederland komt momenteel geen AVP voor. De aandacht voor AVP beperkt zich primair tot het bevestigen van de vrij-status, het faciliteren van vroege detectie, en het nemen van preventieve maatregelen om introductie in Nederland te voorkomen. Daarnaast is er aandacht voor een effectieve bestrijding mocht zich hier een uitbraak voordoen.

Voor bevestiging van de vrij-status en het faciliteren van vroege detectie worden in Nederland meerdere monsterstromen standaard getest op AVP, hetzij middels serologische testen, hetzij middels PCR:

- Monitoring wilde zwijnen: 400-500 monsters op jaarbasis voor serologische diagnostiek;

- Early warning KVP: 300-400 monsters (50-70 inzendingen) op jaarbasis voor PCR-diagnostiek;

- Verdenkingen AVP of KVP: 5-15 monsters op jaarbasis (1-10 verdenkingen) voor PCR-diagnostiek.

\section{Introductiekans AVP in Nederland}

De kans op insleep van AVP-virus in Nederland is duidelijk gestegen in vergelijking met de vorige convenantperiode als gevolg van de ontwikkelingen in (Oost-)Europa in de laatste jaren en met name de zeer recente ontwikkelingen in België bij wilde zwijnen.

De kans op introductie van AVP-virus in Nederland kan langs verschillende paden lopen:

\section{Directe introductie naar gedomesticeerde varkens}

a. Directe introductie naar Nederland door import van met AVP-virus geïnfecteerde gedomesticeerde varkens op Nederlandse varkensbedrijven; deze kans wordt geschat als 1 keer per 50 jaar;

b. Directe introductie van met AVP-virus geïnfecteerd (wilde) varkensvlees dat als swill aan gedomesticeerde varkens op Nederlandse varkensbedrijven wordt gevoerd door de varkenshouder; deze kans wordt geschat als 1 keer per 40 jaar;

c. Directe introductie van met AVP-virus gecontamineerd (wilde) varkensvlees dat als afvalresten van een maaltijd door bijvoorbeeld toeristen over het hek wordt gegooid bij gedomesticeerde, in een uitloop of als natuurvarken volledig buiten gehouden varkens op Nederlandse varkensbedrijven; deze kans wordt geschat als 1 keer per 10 jaar.

Indirecte introductie naar gedomesticeerde varkens (via contact met AVP-virus besmette wilde zwijnen)

a. Introductie van AVP-virus in wilde zwijnen door direct contact van met AVP-virus geïnfecteerde wilde zwijnen uit het buitenland die vrijwillig de grens oversteken en met Nederlandse wilde zwijnen in contact komen; deze kans wordt geschat als 1 keer per 10 jaar;

b. Introductie van AVP-virus in Nederlandse wilde zwijnen doordat zij met AVP-virus gecontamineerde etensresten eten die bijvoorbeeld bij parkeerplaatsen in Nederland zijn achtergelaten door toeristen of transportwagenchauffeurs; deze kans wordt geschat op 1 keer per 2 jaar.

c. Introductie van AVP-virus in wilde zwijnen door direct contact van AVP-virus geïnfecteerde wilde zwijnen uit het buitenland - die illegaal geïmporteerd worden in verband met het vergroten van de te bejagen wildezwijnenpopulatie - en met Nederlandse wilde zwijnen in contact komen; deze kans is zeer moeilijk te schatten in verband met het illegale karakter (maar onwaarschijnlijk vanwege grote bestand van wilde zwijnen in Nederland). 
Als er wilde zwijnen in Nederland met AVP-virus besmet raken, gaan we ervan uit, op basis van de ervaringen in Oost-Europa tot nu toe, dat de infectie een endemische vorm zou kunnen aannemen. België probeert op dit moment met zijn aanpak ervoor te zorgen dat een endemische vorm van de infectie onder de wilde zwijnen niet wordt bereikt. De komende tijd zal moeten blijken of dit gaat lukken, en als het lukt om de endemische vorm te voorkomen is dat een heel belangrijke overwinning waardoor het risico op verspreiding naar gedomesticeerde varkens wordt verlaagd. Nederland zal Europese regelgeving aanhouden, wat betekent dat gebieden met geïnfecteerde wilde zwijnen worden geïsoleerd en dat er een verbod komt op het buiten houden van gedomesticeerde varkens. Dit zal de kans op overdracht van AVP-virus van geïnfecteerde wilde zwijnen naar gedomesticeerde varkens verlagen.

Wij vinden het moeilijk om aan te geven wat de kans zou zijn op overdracht van AVP-virus van geïnfecteerde wilde zwijnen naar gedomesticeerde varkens in Nederland. Puttend uit de situatie en huidige ervaring in België (d.d. 3 Januari 2019), waar er tot nu toe nog steeds geen overdracht heeft plaatsgevonden naar gedomesticeerde varkens vanuit de geïnfecteerde wilde zwijnen, verwachten wij dat die kans niet hoog zal zijn met in achtneming van de verwachte werking van ingestelde maatregelen van de Europese regelgeving.

\subsection{Mond-en-klauwzeer (MKZ)}

Huidige situatie in Nederland

Nederland heeft sinds het ingaan van het Europese non-vaccinatiebeleid voor MKZ vanaf 1991 in totaal een keer een insleep van MKZ-virus meegemaakt, in 2001. Dit levert een initiële introductiekans op van 1 keer per 28 jaar.

Situatie in omringende landen, Europa en Noord-Afrika

Armenië: 2015, 2016

Bulgarije: 2011

Rusland: ieder jaar in de periode 2010-2017

Turkije: ieder jaar in de periode 2010-2018

Algerije: 2014-2017

Israël: 2013, 2014, 2015, 2017, 2018

Palestijnse Autoriteit: 2013-2017

Libië: 2013, 2014

Marokko: 2015

Tunesië: 2014, 2017.

In tabel 2.2 zijn de herkomstlanden van geïmporteerde (nuchtere) kalveren weergegeven. Deze dieren zouden op kunnen treden als potentiele bron van MKZ-virus introductie. 
Tabel 2.2 Overzicht van import van nuchtere kalveren ( $<2$ maanden leeftijd) naar Nederland naar oorsprong uit Europese landen

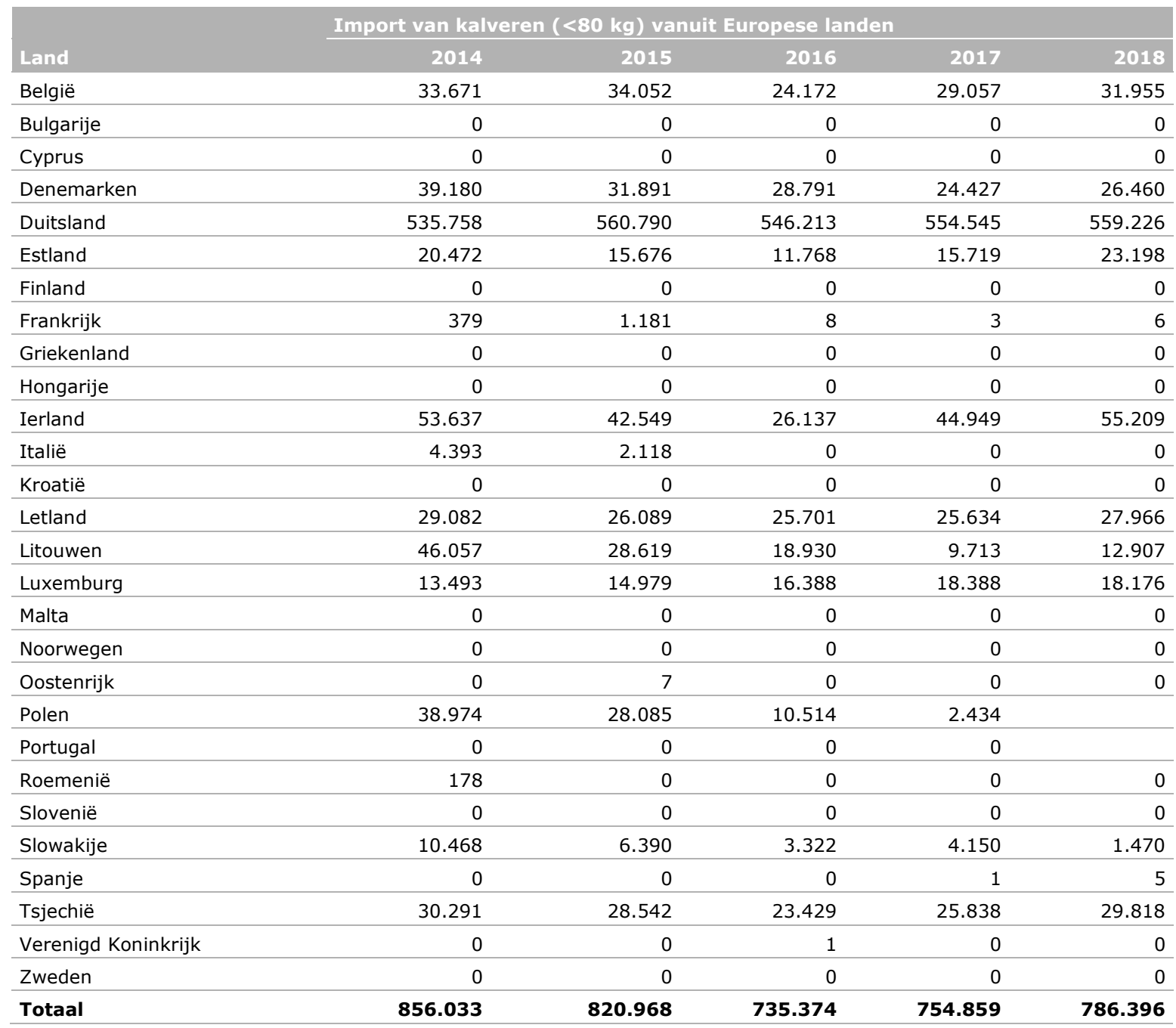

Bron: RVO I\&R Dierregistraties. Er is een verschil tussen CBS Statline en I\&R Dierregistraties. Welke bron de juiste gegevens bevat is moeilijk aan te geven. Voor deze rapportage gebruiken we de I\&R-gegevens als uitgangspunt.

De grootste kans op insleep van MKZ zou zijn door import van runderen/kalveren vanuit Bulgarije, Roemenië en/of Griekenland in verband met de korte afstand tot Turkije, dat een MKZ-risicoland is.

\section{Conclusie introductiekans $M K Z$}

De introductiekans lijkt niet hoger geworden dan bij de vorige convenantperiode (2015-2019). In Turkije is MKZ al vele jaren endemisch aanwezig en kan zich verspreiden naar de omringende landen zoals we recent hebben gezien voor twee andere infectieuze dierziekten: Lumpy skin disease en Peste des petits ruminants. Verder kan verwacht worden dat als gevolg van de naderende Brexit, de importstromen van kalveren zich weer zullen verleggen, wat een verhoging van het risico zou kunnen betekenen. $^{2}$

$\mathrm{Er}$ is bij de vorige convenantperiode aangegeven dat als er geen kalveren meer zouden worden aangevoerd vanuit Roemenië, en er niet opnieuw gestart zou worden met aanvoer vanuit Bulgarije, er aanleiding zou kunnen zijn om de introductiekans te verlagen. Aangezien de I\&R-gegevens geen invoer van kalveren uit deze risicolanden laat zien, kunnen we daarom concluderen dat de introductiekans verlaagd kan worden ten opzichte van de vorige convenantperiode naar 1 keer per 15 jaar (was 1 per 10 jaar).

\footnotetext{
2 Nu worden in Nederland geen kalveren uit het VK door de Nederlandse vleeskalverhouderij ingezet. Britse kalveren gaan nu vooral naar Spanje en Italië. Indien deze landen niet meer uit het VK kunnen importeren, worden handelsstromen mogelijk verschoven.
} 


\subsection{Hoog-pathogene aviaire influenza (HPAI)}

\section{Introductie ${ }^{3}$}

Aviaire Influenza (AI)-virussen komen wereldwijd voor, zowel bij gedomesticeerd pluimvee als bij wilde (water)vogels, met name van de ordes Anseriformes (i.e. eenden, ganzen en zwanen) en Charadriiformes (i.e. steltloperachtige en meeuwen). De meeste AI-virustypen zijn laag-pathogeen (LPAI) en komen zeer algemeen voor bij wilde watervogels, die fungeren als virusreservoir voor alle AI typen. Subtype H5- en H7-AI-virussen kunnen echter muteren van laag- naar hoog-pathogene aviaire influenza (HPAI). HPAI veroorzaakt grote sterfte onder gedomesticeerd pluimvee. Er zijn aanwijzingen dat deze mutaties van laag-pathogeen naar hoog-pathogeen enkele keren zijn opgetreden in het verleden, waaronder onder andere bij de H7N7-epidemie in 2003 in Nederland. Naast een mutatie binnen pluimvee bestaat de mogelijkheid dat deze mutaties plaats vinden in vogels die minder gevoelig zijn voor het virus en HPAI-virus kunnen verspreiden naar het commerciële pluimvee (directe insleep).

De laatste jaren worden de AI-virussen ingedeeld in Notifiable Aviaire Influenza (NAI-)virussen, de subtypen $\mathrm{H} 5$ en $\mathrm{H} 7$, en $\mathrm{AI}$ van de andere subtypen die niet bestrijdingsplichtig zijn. De NAIintroductiekans wordt samengesteld uit: a) de directe introductiekans van HPAI; b) de introductiekans van Laag-pathogene Notifiable Aviaire Influenza (LPNAI) gekoppeld aan de kans op mutatie van LPNAI naar HPAI.

De directe introductie van HPAI-virus met wilde vogels naar landen in Noordwest-Europa was tot enkele jaren geleden uitzonderlijk. Met de komst van het HPAI-subtype H5N1-virus uit Zuidoost-Azië naar Europa eind 2005 werd voor het eerst waargenomen dat HPAI-virus direct met wilde (water)vogels kon worden geïntroduceerd in de omgeving van commerciële pluimveebedrijven. Deze directe introductieroute van HPAI-virus met wilde vogels naar landen in Noordwest-Europa is de laatste jaren een algemeen gegeven geworden.

\section{Situatie wereldwijd}

In de laatste 13 jaar zijn twee wereldwijde golven van HPAI te onderscheiden. De eerste golf vond plaats van 2004 tot 2012 met het hoogtepunt in 2006. Er zijn in deze periode geen uitbraken in Nederland vastgesteld. De reden is dat er of geen wilde vogels besmet met HPAI-virus in Nederland aangekomen, of de wilde vogels zijn wel aangekomen maar met een hele lage 'virus-load', waardoor de kans op besmetting van commerciële pluimveebedrijven vanuit een gecontamineerde omgeving zeer klein was.

Wij kunnen weinig zeggen (en zeker niet met enige zekerheid) over aan- of afwezigheid van HPAIvirus in migrerende wilde vogels die in Nederland (enige tijd) verblijven omdat er nauwelijks tot geen metingen plaatsvinden in het risicoseizoen van aanwezigheid van virus bij migrerende wilde vogels. ${ }^{4}$

In 1996 werd het HPAI H5N1-virus voor het eerst gedetecteerd in China en sindsdien wordt het virus regelmatig gerapporteerd in pluimvee en wilde vogels in Azië en Afrika. Eind 2005 werd de Aziatische H5N1 geïntroduceerd in Europa, waarna het virus werd gedetecteerd in zowel wilde vogels als pluimvee in verschillende landen. De laatste HPAI H5N1-uitbraak was in 2015 in Frankrijk, maar dit virus was niet gerelateerd aan andere Aziatische HPAI H5N1-virussen, dus waarschijnlijk is dit virus geëvolueerd uit een LPAI Europees virus. H5N1 vormt een volksgezondheidsrisico: in juli 2018 zijn er in totaal 860 humane infecties in Azië en Afrika gerapporteerd bij de WHO. Deze humane infecties zijn allemaal geassocieerd met nauw contact met geïnfecteerde vogels of een H5N1 gecontamineerde omgeving.

De tweede golf met HPAI-uitbraken is gestart in 2013, die zijn hoogtepunt kende in 2015 en 2017 en deze golf duurt tot op heden voort. In de laatste vijf jaar zijn er door verschillende circulerende subtypen, een groot aantal pluimveebedrijven in landen over de hele wereld getroffen door HPAI.

\footnotetext{
3 Gebaseerd op Gemeraad et al. (2018).

4 Vaststellen van een mate van aanwezigheid van HPAI-virus bij migrerende wilde vogels is niet eenvoudig omdat het waarschijnlijk zoeken is naar een speld in een hooiberg en een grote hoeveelheid monsters vergt om met zekerheid uitspraken te kunnen doen over de aan- of afwezigheid.
} 
Figuur 2.1 geeft een overzicht van de landen die van januari 2013 tot juli 2018 minimaal één HPAIuitbraak in pluimvee hebben gerapporteerd en per continent worden de gedetecteerde subtypen weergegeven.

In China zijn er grote problemen met het hoog pathogene H7N9. In 2013 werd het LPAI H7N9-virus voor het eerst gedetecteerd in China, maar in Februari 2017 is dit virus in pluimvee gemuteerd tot HPAI en is het verspreid door heel China. Dit H7N9-virus is een significant risico voor de humane gezondheid, want sinds 2013 heeft het meer dan 1.600 humane infecties veroorzaakt. De Chinese overheid heeft eind 2017 een vaccinatieprogramma gestart in pluimvee, waarna het aantal infecties is afgenomen: in de periode van 21 maart 2018 tot eind augustus werden er nog vier meldingen van H7N9 in pluimvee gemaakt door China. Door het verminderde aantal infecties in pluimvee raken ook minder mensen geïnfecteerd.

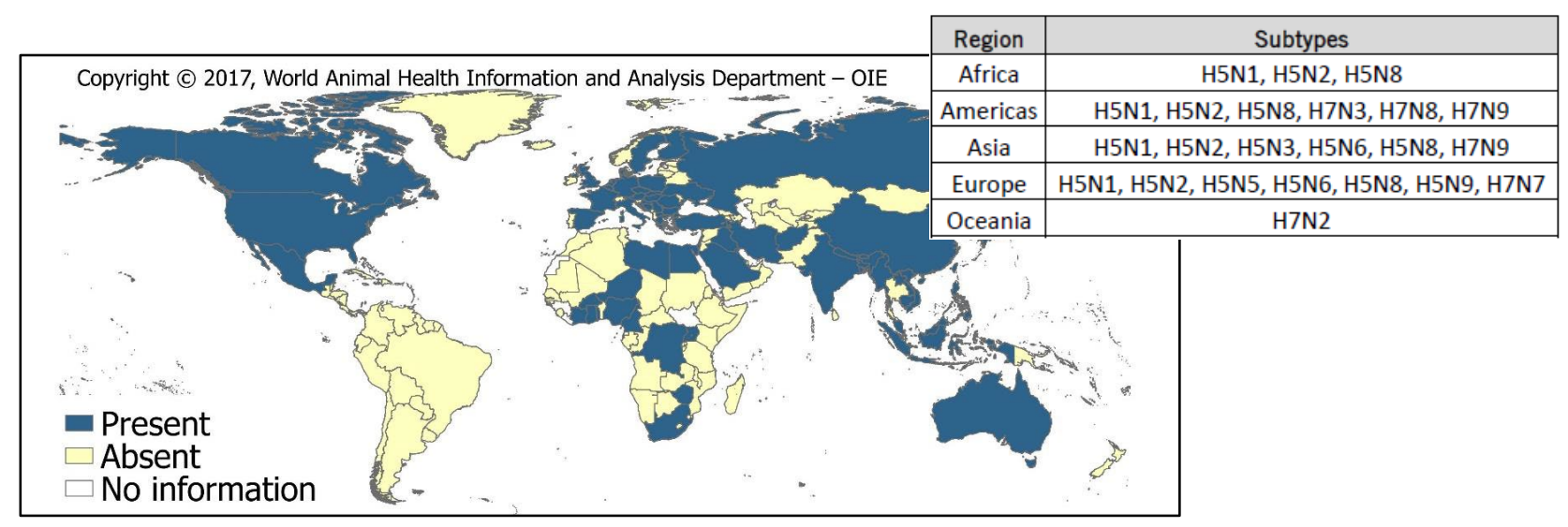

Figuur 2.1 Overzicht van de landen waar minimaal één HPAI-uitbraak is gerapporteerd in pluimvee in de periode januari 2013 tot en met juli 2018. Per continent worden de gedetecteerde subtypen weergegeven

Bron: OIE situation report HPAI.

Het HPAI H5N8-virus veroorzaakt nog steeds talrijke infecties in pluimvee en wilde vogels in Europa, Afrika, het Midden-Oosten en Azië. In 2014 werden verschillende pluimveebedrijven in Europa, en ook in Nederland, getroffen door het H5N8 groep A-virus. In 2016 werd het H5N8 groep B-virus in Europa en Nederland geïntroduceerd. Het H5N8 groep B-virus veroorzaakte grote sterfte onder de wilde vogels, en in Nederland raakten ook verschillende pluimveebedrijven besmet. Het virus werd voornamelijk gevonden in landen die liggen op de vliegroutes van migrerende vogels. In 2018 is het H5N8 groep B-virus, als eerste HPAI in de geschiedenis, doorgedrongen tot aan Zuid-Afrika. Zeldzame wilde vogels, pinguïns en struisvogels worden bedreigd en tot op heden wordt het virus nog steeds gedetecteerd in wilde vogels (13 juli 2018).

Het HPAI H5N6-virus werd voor het eerst gedetecteerd in 2013 (China) en vervolgens werd het virus ook aangetoond in pluimvee in andere Aziatische landen. Dit virus heeft in Azië enkele humane (dodelijke) infecties veroorzaakt (19 casussen in de periode van 2014 tot juli 2018). Eind juli is dit virus voor het laatst gedetecteerd op 3 pluimveebedrijven in Vietnam. In 2017 werd ook in Europa HPAI H5N6 aangetoond in wilde vogels en pluimvee. Echter, dit betreft een andere variant van het virus, het H5N6-virus in Europa is verwant aan het H5N8 groep B-virus uit 2016. Deze H5N6-variant heeft, in tegenstelling tot het H5N6-virus in Azië, geen zoönotisch karakter. Het virus is nog niet verdwenen uit Europa: op 9 augustus 2018 heeft Denemarken nog een wilde zwaan gevonden die besmet was met H5N6.

Sinds 2012 worden er H5N2 HPAI-uitbraken gerapporteerd vanuit Taiwan. In de periode van 21 maart tot eind augustus 2018 zijn er 31 meldingen gedaan van H5N2 HPAI in pluimvee. Afgelopen zomer is er ook een H5N2-virus gemeld in Rusland waar een commercieel pluimveebedrijf besmet is geraakt. Tot op heden is het onduidelijk of deze virussen aan elkaar gerelateerd zijn. 


\section{Situatie in Europa}

In tabel 2.3 wordt een overzicht gegeven van het aantal HPAI-introducties (inclusief in wilde fauna) in Europese landen in de periode 2010-2018 (Bron: WAHID, OIE). In de periode 2014-2018 vinden vrijwel jaarlijks HPAI-introducties plaats in Europese landen.

Tabel 2.3 Overzicht Aantal HPAI-introducties (inclusief wilde fauna) in Europa

\begin{tabular}{|c|c|c|c|c|c|c|c|c|c|}
\hline Land & 2010 & 2011 & 2012 & 2013 & 2014 & 2015 & 2016 & 2017 & 2018 \\
\hline België & & & & & & & & 2 & \\
\hline Bosnië en Herzegovina & & & & & & & & 1 & \\
\hline \multicolumn{10}{|l|}{ Cyprus } \\
\hline Denemarken & & & & & & & 38 & & * \\
\hline \multicolumn{10}{|l|}{ Estland } \\
\hline Finland & & & & & & & 9 & 4 & * \\
\hline Frankrijk & & & & & & 67 & 118 & 389 & \\
\hline \multicolumn{10}{|l|}{ Griekenland } \\
\hline \multicolumn{10}{|l|}{ Ierland } \\
\hline Kroatië & & & & & & & 5 & 9 & \\
\hline \multicolumn{10}{|l|}{ Letland } \\
\hline \multicolumn{10}{|l|}{ Litouwen } \\
\hline \multicolumn{10}{|l|}{ Luxemburg } \\
\hline \multicolumn{10}{|l|}{ Malta } \\
\hline Nederland & & & & & 5 & 1 & 47 & 17 & * \\
\hline \multicolumn{10}{|l|}{ Noorwegen } \\
\hline Oostenrijk & & & & & & & 28 & 1 & \\
\hline Polen & & & & & & & 27 & 43 & \\
\hline Spanje & & & & & & & & 10 & \\
\hline Tsjechië & & & & & & & & 38 & \\
\hline Turkije & & & & & & 3 & & & \\
\hline Verenigd Koninkrijk & & & & & 1 & 1 & 13 & 17 & * \\
\hline Zweden & & & & & & 2 & 16 & 4 & \\
\hline Zwitserland & & & & & & & 84 & & \\
\hline
\end{tabular}

\# Sept. 2018 zijn in Nederland op twee verschillende locaties dode wilde vogels met HPAI-subtype H5N6-virus vastgesteld. Bron: WAHID, OIE.

\section{Situatie in Nederland}

In 2003 werd Nederland opgeschrikt door een grote HPAI-epidemie (H7N7-subtype) in pluimvee; een LPAI-subtype H7N7-virus werd geïntroduceerd in een stal met uitloop, waarna het LPAI H7N7 is gemuteerd naar een hoog-pathogene vorm (HPAI) in de stal zonder uitloop op het pluimveebedrijf. Het HPAI-virus is vervolgens sterk gaan spreiden in het pluimveedichte gebied op de Veluwe. Vijfenzeventig jaar daarvoor was de laatst geregistreerde HPAI-uitbraak (waarschijnlijk geen directe HPAI-insleep maar ook een mutatie naar HPAI na een LPAI-insleep), overigens in dezelfde regio als waar de 2003-epidemie startte. De situatie in 2003 kan daarmee in epidemiologische zin gekenschetst worden als een eenmalige (onafhankelijke) introductie van HPAI-virus in Nederland (mutatie van LPAI naar HPAI-virus op één commercieel pluimveebedrijf), waarna het sterk is gaan spreiden naar andere pluimveebedrijven. 
Ten tijde (eind 2014) van de bespreking van het rapport voor de vorige convenantperiode (20152019) ten behoeve van de onderbouwing van de DGF-plafondbedragen, werd Nederland opgeschrikt door de introductie van HPAI H5N8-virus bij pluimvee. Er werden uiteindelijk 5 pluimveebedrijven besmet: op in ieder geval 4 pluimveebedrijven waren er afzonderlijke (onafhankelijke) introducties (dus geen tussenbedrijfverspreiding), bij het vijfde pluimveebedrijf kon dit niet met zekerheid worden vastgesteld: of een afzonderlijke introductie uit dezelfde bron in de omgeving of mogelijk verspreiding vanuit het $4 \mathrm{e}$ besmette bedrijf dat in de omgeving lag. Er waren sterke aanwijzingen dat het virus naar de omgeving van de pluimveebedrijven was gebracht door migrerende wilde watervogels. De uitbraken vonden plaats in waterrijke omgevingen met een relatief lage dichtheid aan pluimveebedrijven.

Eind 2016 waren er afzonderlijke (onafhankelijke introducties (zonder aanwijzingen voor tussenbedrijfverspreiding) van een HPAI N5N8-virus (andere genetische samenstelling als die van 2014) op negen commerciële pluimveebedrijven in Nederland. Ook hier waren er zeer sterke aanwijzingen dat het virus naar de omgeving van de pluimveebedrijven was gebracht door migrerende wilde watervogels. De uitbraken vonden plaats in waterrijke omgevingen met een relatief lage dichtheid aan pluimveebedrijven. Eind 2017 en begin 2018 waren er afzonderlijke introducties van het HPAI H5N6-virus op drie commerciële pluimveebedrijven in Nederland (zonder aanwijzingen voor tussenbedrijf verspreiding). Er waren sterke aanwijzingen dat het virus naar de omgeving van de pluimveebedrijven was gebracht door migrerende wilde watervogels. De uitbraken vonden ook hier plaats in waterrijke omgevingen met een relatief lage dichtheid aan pluimveebedrijven.

De situatie in de periode 2014-2018 is daarmee sterk verschillend van de situatie in 2003 (toen er vanuit één commercieel HPAI-besmet commercieel pluimveebedrijf sterke verspreiding heeft plaats gevonden naar andere pluimveebedrijven), omdat er in een tijdsbestek van 4 jaar in totaal 17 introducties zijn geweest waarvan ten minste 16 introducties als afzonderlijke/onafhankelijke introducties (zonder tussenbedrijfverspreiding) kunnen worden beschouwd.

In September 2018 zijn in Nederland op twee verschillende momenten dode wilde vogels gevonden in het Eemmeer waarin HPAI-subtype H5N6-virus is vastgesteld. Omdat dit ook op andere plaatsen in Europa is gebeurd, lijken dat aanwijzingen dat het virus in Europa heeft overzomerd.

\section{Conclusie directe HPAI-introductiekans}

De directe HPAI-introductiekans voor Nederland, maar ook voor een groot aantal andere Europese landen, is zeer sterk toegenomen in vergelijking met de vorige convenantperiode. Sinds de laatste convenantperiode zijn er in de afgelopen vier AI-seizoenen (herfst en winter 2014-2015, 2015-2016, 2016-2017 en 2017-2018) in totaal 17 introducties geweest van HPAI, waarvan waarschijnlijk ten minste 16 introducties kunnen worden gekenschetst als afzonderlijke/onafhankelijke introducties bij commercieel pluimvee in Nederland. De directe HPAI-introductiekans wordt daarom geschat op gemiddeld 16 keer per 4 AI-seizoenen: 4 introducties per jaar. Deze introductiekans wordt gesplitst in:

a. Een kans van 0,75 per jaar op een HPAI-seizoen (3 uit 4 seizoenen);

b. Gemiddeld 5,33 uitbraken per HPAI-seizoen (16 afzonderlijke/onafhankelijke uitbraken in 3 seizoenen).

\section{Introductiekans LPNAI}

In de periode 2010 tot en met half 2018 zijn er in totaal 55 LPAI-subtype H5/H7-virusintroducties op pluimveebedrijven geweest (tabel 2.4). In de periode 2010-2014 waren er gemiddeld 7,4 LPNAIintroducties per jaar (37 introducties in een periode van 5 jaar). In de periode 2015-2018 waren er gemiddeld 4,5 LPNAI-introducties per jaar (18 introducties in een periode van 4 jaar), dit is duidelijk lager dan in de periode 2010-2014. Een mogelijke verklaring voor dit verschil tussen de perioden kunnen wij op dit moment niet geven, het kan een toevallige fluctuatie in de tijd zijn. 
Tabel 2.4 Overzicht Aantal LPAI-subtype H5/H7-virusintroducties bij pluimveebedrijven in Nederland

\begin{tabular}{lr} 
Jaartal Aantal LPAT-subtype H5/H7-virusintroducties bij pluimveebedrijen in Nederland & 5 \\
\hline 2010 & 9 \\
\hline 2011 & 2 \\
\hline 2012 & 10 \\
\hline 2013 & 11 \\
\hline 2014 & 5 \\
\hline 2015 & 5 \\
\hline 2016 & 4 \\
\hline 2017 & 4 \\
\hline 2018 & \\
\hline
\end{tabular}

Het is moeilijk om een inschatting te maken van de kans op mutatie van LPAI-virus naar HPAI-virus. Een recente wetenschappelijke opinie van de EFSA uit $2017^{5}$ geeft aan dat er in Europa in een beperkt aantal gevallen kon worden bewezen dat HPAI uitbraken waren veroorzaakt door mutatie van LPAIv naar HPAIv. Er konden geen specifieke factoren worden aangewezen die gerelateerd zouden zijn aan het bevorderen van mutatie zoals gastheer species, omgevingsfactoren of viruslijnen en er zijn geen moleculaire markers gevonden die zonvolle voorspellers zouden zijn voor verhoogd risico voor mutatie van LPAIv naar HPAIv. De huidige kennis staat niet toe om een voorspelling te kunnen doen of, en wanneer LPAI-virus zal muteren naar HPAI-virus.

Het is overigens zeer aannemelijk dat de mutatiekans toeneemt als het LPAI-virus een langere tijd heeft om te spreiden binnen een geïnfecteerd koppel pluimvee of tussen koppels in een gebied. Vandaar dat er internationaal is afgesproken om LPAI-uitbraken van het H5- en H7-subtype te bestrijden. Gelukkig is de ervaring in Nederland tot nu toe na de grote HPAI H7N7-epidemie in 2003, dat de veterinaire autoriteiten er in een redelijk aantal gevallen relatief vroeg bij zijn na introductie van het virus in het pluimvee. Daardoor zal, als de huidige wijze van surveillance (frequentie van bemonsteren en aantallen te bemonsteren pluimveebedrijven), alertheid bij pluimveehouders en bereidheid bij pluimveehouders tot melden van een verdachte situatie op hetzelfde peil blijft als in de afgelopen jaren, de kans op mutatie beperkt blijven, en zeer waarschijnlijk $<1 \%$ bedragen. Daarmee wordt de kans op mutatie van LPNAI naar HPAI in de Nederlandse situatie, met de bovengenoemde voorwaarden, als zeer beperkt ingeschat.

Er werd in het EFSA-rapport verder geconstateerd dat mutatie van LPAIv naar HPAIv meer voorkomt bij LPAI-subtype H7-virussen dan subtype H5-virussen. Voor LPAI-virussen is waargenomen dat er per jaar/jaren verschil kan zitten in het optreden van een dominant type: welk type het meest wordt gevonden, zowel in wilde vogels als in pluimvee. Het is aannemelijk dat immuniteit hierbij een rol speelt. Na infectie met LPAI-virus heeft ook de wilde vogel afweerstoffen en is daarmee (beter) beschermd tegen een infectie met een influenza virus van het zelfde $\mathrm{H}$-subtype. Bij wilde vogels is er ten aanzien van HPAI weinig bekend over de dynamiek van infectie tussen verschillende jaren. Wat we wel hebben gezien is dat er HPAI H5-subtypen rondgaan die meer of minder sterfte geven in wilde vogels. Het kan zo zijn dat de HPAI-virussen die beperkt sterfte geven in wilde vogels, wel immuniteit geven waardoor het risico dat het virus met migrerende wilde vogels naar Europa komt lager zou zijn. Maar hierover is nog te weinig kennis aanwezig en er worden niet systematisch gegevens verzameld om hier jaarlijks een overwogen voorspelling over te kunnen doen.

\section{Conclusie introductiekans HPAI}

In de vorige convenantperiode is de introductiekans van HPAI (direct en indirect via mutatie uit LPNAI) geschat op 1 keer per 5 jaar. Op basis van de regelmatige, afzonderlijke/onafhankelijke directe introducties van HPAI-virus in Nederland op commerciële pluimveebedrijven in de afgelopen jaren en de verwachting dat die situatie zich niet zal verbeteren in de komende jaren als gevolg van de endemische situatie van HPAI-virus in (Zuidoost-)Azië, wordt voor de komende convenantperiode de HPAI-introductiekans geschat op gemiddeld 4 keer per jaar.

\footnotetext{
5 Avian Influenza; doi: 10.2903/ j.efsa.2017.4991
} 


\subsection{Rundertuberculose}

\section{Situatie in Nederland}

Bovine tuberculose (bTB) is endemisch in Europa. Nederland is officieel bTB-vrij, maar bTB wordt wel af en toe aangetroffen in runderen in Nederland als gevolg van import van besmette dieren. In tabel 2.5 zijn de herkomstlanden van de bTB-uitbraken in Nederland in de periode 1999-2018 weergegeven.

Tabel 2.5 Overzicht Bovine Tuberculose-uitbraken bij rundveebedrijven in Nederland in de periode 1999-2018 naar herkomstland als bron en bedrijfstype. Alleen jaren met uitbraken zijn weergegeven

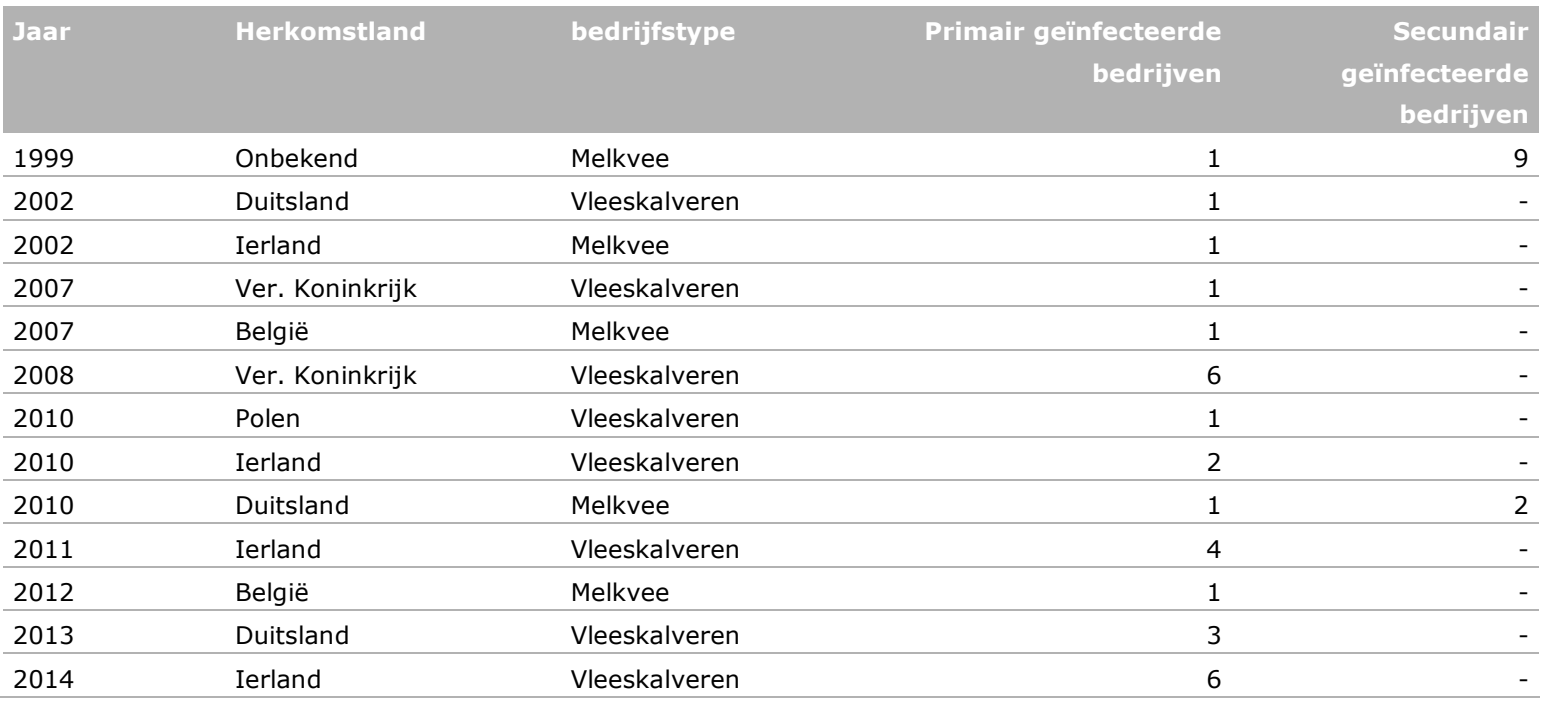

Elk jaar is er waarschijnlijk wel insleep van bTB in Nederland (introductiekans $=1$ ), vooral via import van kalveren (De Vos et al., 2015). Maar deze insleep leidt vrijwel nooit tot een uitbraak en verdere verspreiding. Insleep van bTB wordt ook lang niet altijd gedetecteerd omdat het lang duurt voordat klinische verschijnselen zichtbaar zijn. De vleeskalveren zijn dan allang geslacht voordat er een infectie wordt gedetecteerd. Voor spreiding van de infectie vormen ze een verwaarloosbaar gevaar omdat ze geslacht zijn voordat er transmissie kan optreden. De insleep van bTB via kalveren is daarom niet van belang voor het DGF.

Volwassen runderen (fok- en gebruiksvee) met bTB zijn echter wel van belang. In Nederland worden momenteel geïmporteerde runderen niet getest op bTB; bij een steekproef van circa 8\% (tussen de 5 en $10 \%$ ) van geïmporteerde runderen wordt er gekeken naar klinische verschijnselen van bTB. Dit zal vrijwel nooit leiden tot detectie van bTB-geïnfecteerde runderen gegeven de zeer lage sensitiviteit van klinische inspectie. Bij het slachten van volwassen runderen kan door tuberculose aangetast longweefsel worden opgemerkt aan de slachtlijn, maar dit resulteert meestal in een verlate detectie omdat bTB dan veelal al lange tijd op een rundveebedrijf aanwezig is en heeft kunnen spreiden naar andere runderen op het bedrijf of kunnen spreiden naar andere bedrijven doordat geïnfecteerde runderen zijn verkocht naar andere bedrijven. Daarnaast moet worden opgemerkt dat bTB in de wilde fauna endemisch kan voorkomen en dus een gevaar vormt voor het overspringen naar gedomesticeerde dieren. Voorbeelden van bTB-reservoirs in de wilde fauna zijn de wilde zwijnen in Spanje, herten in Duitsland, Oostenrijk, Zwitserland en Oost-Europa en de dassen in het Verenigd Koninkrijk en ROI. In Nederland vindt surveillance op bTB in de wilde fauna plaats (in andere landen in Europa is dit vaak minder goed geregeld), maar de sensitiviteit daarvan is niet zo groot.

Zolang er geen extra diagnostiek op geïmporteerde runderen wordt uitgevoerd (zoals voorgesteld door de Vos et al., 2015, maar niet geïmplementeerd tot nu toe), schatten wij de volgende introductiekansen in voor bTB in Nederland op basis van de beschikbare gegevens uit de voorgaande schattingen: Fok en gebruiksdieren: 5 bedrijven in 20 jaar: 1 keer per 4 jaar; Kalveren: 24 bedrijven in 20 jaar: 1,2 keer per jaar. 


\section{De epidemiologische gevolgen van een uitbraak van KVP, MKZ en HPAI}

\subsection{Aanpak modellering van transmissie}

Als er een introductie van het virus plaatsvindt in Nederland, hoe zal dit zich dan verder verspreiden tussen bedrijven en wanneer eindigt deze verspreiding uitgaande van bestrijding uitgevoerd volgens het beleidsdraaiboek? Om dit te berekenen wordt gebruikgemaakt van epidemiologische simulatiemodellen die de meest recente inzichten in de verspreiding tussen bedrijven incorporeren. Deze modellen maken daarnaast gebruik van actuele bedrijfsdata (18 juli 2018) voor alle veehouderijbedrijven met gevoelige dieren (locatie \& diersoort \& omvang). Het resultaat van de berekeningen is een set van 10.000 mogelijke epidemieën, waaruit onder meer een verdeling (gemiddelde en percentielen) van grootte en duur van de epidemie kan worden bepaald. Elke individuele epidemie hierin komt tot stand door modelsimulatie volgens een tweetrapsraket, namelijk verspreiding voor de eerste uitbraakdetectie, en verspreiding en bestrijding na de eerste uitbraakdetectie.

De verspreiding voor de eerste uitbraakdetectie maakt gebruik van expertinschattingen (tabel 3.1) van het gemiddeld aantal geïnfecteerde bedrijven op moment van eerste detectie. Deze inschattingen zijn verkregen in de workshop met de deskundigenpanel en zijn uitgesplitst in twee scenario's: eerste insleep in een bedrijfsdicht gebied (densely populated livestock area (DPLA) of densely populated poultry area (DPPA)) versus eerste insleep in een bedrijfsarm gebied (sparsely populated livestock area (SPLA) of sparsely populated poultry area (SPPA)). Dit is omdat bij introductie in een bedrijfsdicht gebied een introductie vaker kan uitgroeien tot een grote epidemie dan bij eerste insleep in bedrijfsarme gebieden.

Tabel 3.1 Expertinschatting van het gemiddeld aantal geïnfecteerde bedrijven op het moment van eerste detectie, exclusief het eerst gedetecteerde bedrijf

\begin{tabular}{llrr}
$\begin{array}{l}\text { Ziek } \\
\text { te }\end{array}$ & Gebiedstype & Inschatting 2020- & Analyse 2015- \\
HPAI & DPPA (hoog-risicogebieden, Gelderse Vallei en vergelijkbare dichtheden in & 2024 \\
& Limburg) & 7 & 10 \\
\hline SPPA (elders) & 1 & 3 \\
\hline KVP & DPLA (hoog-risicogebieden, 21\% van bedrijven) & 6 & 6 \\
\hline & SPLA (elders) & 2 & 2 \\
\hline MKZ & DPLA (hoog-risicogebieden: driehoek Apeldoorn-Deventer-Zwolle en & 9 & 9 \\
& vergelijkbare dichtheden) & & 2 \\
\hline & SPLA (elders) & 2 & 2 \\
\hline
\end{tabular}

In de individuele modelsimulaties wordt het bedrijf van eerste insleep telkens willekeurig gekozen uit alle bedrijven in Nederland met dieren gevoelig voor het betreffende virus, waarbij het model voor de verspreiding voorafgaand aan de eerste uitbraakdetectie zo wordt ingesteld dat gemiddeld over een groot aantal simulaties met eerste insleep in een DPLA (SPLA) bedrijf het aantal geïnfecteerde bedrijven op het moment van de eerste detectie gelijk is aan de expertinschatting voor DPLA (SPLA) uit tabel 3.1. Voor HPAI is hiertoe de aanpak voor de modellering van verspreiding voorafgaand aan de eerste uitbraakdetectie onder dezelfde noemer gebracht als voor MKZ en KVP. Het onderscheid tussen DPLA- en SPLA-bedrijven wordt gemaakt op basis van het lokale reproductiegetal voor transmissie tussen bedrijven, dat met behulp van het tussenbedrijfstransmissiemodel wordt 
berekend. ${ }^{6}$ Bij de modelaanname van gelijke kans op eerste insleep in alle bedrijven in Nederland betekent dit percentage dat $96 \%$ van de uitbraken start in SPLA-gebieden, dat wil zeggen gebieden met lage dichtheid, en dit is in overeenstemming met de gegevens tot nu toe. Nadat analyses uitwezen dat statistisch significante verbanden voor HPAI tussen locaties van insleep en specifieke vogelrijke gebieden en typen waterlichamen vooralsnog afwezig zijn, is ervan afgezien om binnen de SPLA-gebieden de kans te differentiëren tussen waterrijke en minder waterrijke gebieden.

De transmissiemodellen die gebruikt zijn om dierziekte epidemieën te simuleren, zijn eerder beschreven en gepubliceerd voor KVP (Backer et al., 2009), MKZ (Backer et al., 2012) en HPAI (Backer et al., 2011). De verspreiding van de verschillende dierziektes is gemodelleerd met zogenoemde transmissiekernels, waarbij de infectiekans tussen twee bedrijven afneemt met toenemende afstand. De parameters voor deze kernels zijn geschat uit de uitbraken van KVP in 1997/1998 (Boender et al., 2014), MKZ in 2001 (Boender et al., 2010) en HPAI in 2003 (Boender et al., 2007, met een recente nog niet gepubliceerde update, 2018) in Nederland.

Ten opzichte van de eerdere modelberekeningen zijn bovendien de volgende aspecten in de modelberekeningen geactualiseerd ten opzichte van de vorige convenantperiode:

- Locaties van bedrijven en diersoorten op deze bedrijven, zoals geregistreerd op 18 juli 2018.

- Voor MKZ wordt de toename sinds 2001 van gemiddelde bedrijfsgroottes via een extra parameter (vermenigvuldigingsfactor) verdisconteerd in het tussenbedrijfstransmissierisico. Deze vermenigvuldigingsfactor is geactualiseerd. In verband hiermee is ook de eerdere dynamische modellering van binnenbedrijfstransmissie (waarmee een tijdsverloop van besmettelijkheid en het moment van detectie vervangen werden bepaald) vervangen door een vaste lengte van de periode tussen infectie en detectie en een blokprofiel voor het tijdsverloop van de besmettelijkheid.

- Voor KVP en HPAI is het model uitgebreid met een bedrijfsgrootteafhankelijkheid in de transmissiekernels; dat wil zeggen dat het tussenbedrijfstransmissierisico tussen twee gegeven bedrijven rekening houdt met zowel de bedrijfsgrootte van het geïnfecteerde bedrijf als met die van het nog niet geïnfecteerde bedrijf. Dit betekent dat in deze modellen geen vermenigvuldigingsfactor (meer) nodig is om de toename sinds 1998 (KVP) respectievelijk 2003 (HPAI) in gemiddelde bedrijfsgroottes te verdisconteren. Voor HPAI houdt het model nu bovendien rekening met de diersoort op de bedrijven (vleeskuikens, leghennen, eenden en kalkoenen). Voor KVP is deze verbeterde modellering beschreven in Boender et al. (2014). Voor HPAI is deze modelupgrade zeer recent uitgevoerd en zal eind 2019 worden beschreven in een rapport (project Epitools AI Upgrade). Net als bij MKZ is ook voor KVP en HPAI de eerdere dynamische modellering van binnenbedrijfstransmissie vervangen door een vaste lengte van de periode tussen infectie en detectie en een blokprofiel voor het tijdsverloop van de besmettelijkheid.

- Voor HPAI is de aanpak voor de modellering van verspreiding voorafgaand aan de eerste uitbraakdetectie onder dezelfde noemer gebracht als voor MKZ en KVP, met als gevolg dat er geen gebruik meer gemaakt wordt van resultaten van Interspread-Plus.

In alle scenario's wordt uitgegaan van de volgende bestrijdingsstrategie, in overeenstemming met het beleidsdraaiboek: EU-minimummaatregelen plus, tot de start van noodvaccinatie (KVP en MKZ), preventief ruimen in een straal van $1 \mathrm{~km}$ rondom uitbraakbedrijven; vanaf 6 (KVP) of 11 (MKZ) dagen na de eerste detectie noodvaccinatie in een straal van $2 \mathrm{~km}$ rondom uitbraakbedrijven. In overleg met de opdrachtgever is aangenomen dat bedrijven die op de lijst staan om preventief te worden geruimd, maar nog niet geruimd zijn op het moment dat wordt gestart met noodvaccinatie, op dat moment op de lijst van te vaccineren bedrijven terechtkomen, wat wil zeggen dat preventieve ruiming wordt omgezet in vaccinatie. Voor HPAI is aangenomen dat preventieve ruiming in een straal van $1 \mathrm{~km}$ plaatsvindt gedurende de gehele bestrijdingsperiode.

In de berekeningen zijn maximale ruimingscapaciteit en vaccinatiecapaciteit expliciet ingebouwd. In de modelberekeningen wordt een maximum ruimingscapaciteit van 6 bedrijven per dag en maximum vaccinatiecapaciteit van 120 bedrijven per dag aangenomen, in overeenstemming met actuele inschattingen door de NVWA. Hierbij worden gemengde bedrijven met zowel koppels herkauwers als

\footnotetext{
6 Na een upgrade van het model voor HPAI (beschreven hieronder) is het aantal DPLA ten opzichte van SPLA-bedrijven voor HPAI sterk omlaaggegaan ten opzichte van de berekeningen voor de vorige convenantperiode. Het percentage DPLAbedrijven is nu ongeveer $4 \%$ van het totaal aan pluimveebedrijven.
} 
koppels varkens bij preventieve ruiming voor twee bedrijven geteld, omdat de inzet van twee ruimingsteams vereist is. Na gedachtenuitwisseling met NVWA is daarnaast aangenomen dat bij MKZ preventieve ruiming op volgorde van een gewogen bedrijfsgrootte plaatsvindt; varken telt hierbij zwaarder dan rund (wegingsfactoren 10:1, omdat varkens als sterke verspreiders gelden hebben varkensbedrijven een hoge prioriteit bij preventieve ruiming) en kleine herkauwers tellen minder zwaar dan rund (wegingsfactor 0,1:1); dit betekent onder andere dat een schapenhouderij bij preventief ruimen in het model pas voorrang krijgt op een rundveehouderij of varkenshouderij als het schapenbedrijf minstens tien maal zoveel dieren heeft als de rundveehouderij of varkenshouderij. Gemengde bedrijven worden gewogen volgens de optelsom van gewogen dieraantallen.

Deze aannames zijn een modelbenadering van de praktijk die complexer is en niet geheel te vangen in een rekensom op basis van diersoort en bedrijfsgrootte. Een eventuele achterstand in voorgenomen ruimingen en/of vaccinaties door beperkte capaciteit wordt mee berekend in de tijd, alsmede het effect van zo'n achterstand op het verloop van de epidemie

\subsection{Resultaten modellering van transmissie}

Hieronder worden de resultaten voor de uitbraakduur en -omvang op basis van 10.000 gesimuleerde epidemieën per dierziekte beschreven en vergeleken met de verwachte uitbraakduur en -omvang uit de studie voor de vorige convenantperiode 2015-2019 (Van Asseldonk, 2014). De resultaten worden gegeven voor introductie in Nederland als geheel en uitgesplitst naar introductie in een SPLA versus introductie in een DPLA-bedrijf.

\subsubsection{Omvang uitbraken KVP}

De epidemiologische resultaten voor KVP zijn samengevat in tabel 3.2. Zowel de verwachte duur van de epidemie, met voor heel Nederland een mediaan van 36 dagen, en het aantal gedetecteerde bedrijven, met voor heel Nederland een mediaan van 4 bedrijven, is vergelijkbaar met de eerdere resultaten uit het rapport voor de convenantperiode 2015-2019. Wanneer uitgesplitst naar SPLA versus DPLA zijn de verschillen in de resultaten voor de duur en het aantal gedetecteerde bedrijven met die voor 2015-2019 iets groter maar nog steeds zijn de uitkomsten zeer vergelijkbaar. Voor preventief geruimde en gevaccineerde eenheden zijn de resultaten niet direct te vergelijken met de eerdere, omdat in de huidige berekeningen geruimde en gevaccineerde koppels ${ }^{7}$ worden geteld terwijl de eerdere berekeningen aantallen bedrijven betroffen.

Tabel 3.2 Resultaten (mediaan en (5\%-95\%) interval) voor duur KVP-epidemie en aantallen betrokken bedrijven c.q. koppels, vergeleken met eerdere resultaten voor 2015-2019

\begin{tabular}{|c|c|c|c|c|c|c|c|c|}
\hline \multirow{2}{*}{$\begin{array}{l}\text { Convenant- } \\
\text { periode } \\
\text { ?0-2024 }\end{array}$} & \multicolumn{2}{|c|}{ Duur (dagen) a) } & \multicolumn{2}{|c|}{$\begin{array}{l}\text { Gedetecteerde } \\
\text { bedrijven }\end{array}$} & \multicolumn{2}{|c|}{$\begin{array}{l}\text { Preventief geruimde } \\
\text { koppels }\end{array}$} & \multicolumn{2}{|c|}{$\begin{array}{l}\text { Gevaccineerde } \\
\text { koppels }\end{array}$} \\
\hline & 36 & $(0-156)$ & 4 & $(1-19)$ & 11 & $(0-39)$ & 81 & $(8-490)$ \\
\hline A & 74 & $(0-210)$ & 9 & $(1-29)$ & 24 & $(7-58)$ & 199 & $(0-735)$ \\
\hline $\begin{array}{l}\text { Convenant- } \\
\text { periode }\end{array}$ & \multicolumn{2}{|c|}{ Duur (dagen) a) } & \multicolumn{2}{|c|}{$\begin{array}{l}\text { Gedetecteerde } \\
\text { bedrijven }\end{array}$} & \multicolumn{2}{|c|}{$\begin{array}{l}\text { Preventief geruimde } \\
\text { bedrijven }\end{array}$} & \multicolumn{2}{|c|}{$\begin{array}{l}\text { Gevaccineerde } \\
\text { bedrijven }\end{array}$} \\
\hline L5-2019 b) & 39 & $(7-151)$ & 6 & $(2-18)$ & 3 & $(0-9)$ & 39 & $(8-144)$ \\
\hline - A & 19 & $(3-90)$ & 3 & $(1-8)$ & 2 & $(0-6)$ & 10 & $(1-49)$ \\
\hline A $A$ & 97 & $(20-323)$ & 13 & $(4-48)$ & 7 & $(1-18)$ & 120 & $(27-415)$ \\
\hline
\end{tabular}

In grijs de resultaten voor heel Nederland, wat wil zeggen introductie in Nederland ongeacht lokale bedrijfsdichtheid. a) duur: periode tussen eerste en laatste detectie; b) resultaten uit Van Asseldonk et al. (2014)

\footnotetext{
7 Bij de analyse voor KVP zijn ten behoeve van de economische analyse de aantallen (preventief) geruimde en gevaccineerde bedrijven opgesplitst in vleesvarkens, biggen en zeugen. Bedrijven die twee of drie van deze categorieën combineren zijn daarbij boekhoudkundig opgesplitst in vleesvarken- en/of biggen- en/of zeugengedeelten. In dit verband gebruiken we in deze rapportage het woord 'koppel', hier gedefinieerd als ofwel een bedrijf met slechts één van de categorieën dieren ofwel een gedeelte van een bedrijf met meerdere categorieën.
} 


\subsubsection{Omvang uitbraken MKZ}

De epidemiologische resultaten voor MKZ zijn samengevat in tabel 3.3. Het aantal gedetecteerde bedrijven, met voor heel Nederland een mediaan van 15 bedrijven, is vergelijkbaar met de eerdere resultaten uit het rapport voor de convenantperiode 2015-2019. De mediaan van de voorspelde duur van de epidemie is nu korter dan in de eerdere berekeningen. Dit is mede een gevolg van een verbeterde weging tussen DPLA en SPLA. Hetzelfde geldt voor de mediaan van het voorspelde aantal gevaccineerde koppels. Het aantal preventief geruimde koppels is duidelijk hoger dan in de eerdere berekeningen; hierin speelt een rol dat nu is aangenomen dat pas vanaf dag 11 wordt gevaccineerd in vergelijking met vanaf dag 6 in de eerdere berekeningen. In tabel 3.3 zijn ook de resultaten voor heel Nederland voor 2020-2024 uitgesplitst naar drie sectoren rund, schaap/geit en varken. In de transmissiemodellering is ten behoeve van de economische analyse ook nog boekhoudkundig onderscheid gemaakt tussen melkgeiten en andere geitenkoppels (waarbij de laatste zijn opgenomen in de categorie schaap/geit).

Tabel 3.3 Resultaten (mediaan en (5\%-95\%) interval) voor duur MKZ-epidemie en aantallen betrokken bedrijven c.q. koppels, vergeleken met eerdere resultaten voor 2015-2019

\begin{tabular}{|c|c|c|c|c|c|c|c|c|}
\hline $\begin{array}{l}\text { Convenant- } \\
\text { periode }\end{array}$ & \multicolumn{2}{|c|}{ Duur (dagen) a) } & \multicolumn{2}{|c|}{$\begin{array}{l}\text { Gedetecteerde } \\
\text { bedrijven }\end{array}$} & \multicolumn{2}{|c|}{$\begin{array}{l}\text { Preventief geruimde } \\
\text { koppels }\end{array}$} & \multicolumn{2}{|c|}{$\begin{array}{l}\text { Gevaccineerde } \\
\text { koppels }\end{array}$} \\
\hline $2020-2024$ & 18 & $(0-70)$ & 15 & $(1-69)$ & 37 & $(3-116)$ & 275 & $(0-1846)$ \\
\hline schaap/geit & & & 1 & $(0-4)$ & 10 & $(0-39)$ & 61 & $(0-388)$ \\
\hline varken & & & 0.3 & $(0-2)$ & 7 & $(0-36)$ & 36 & $(0-282)$ \\
\hline DPLA & 41 & $(0-101)$ & 54 & $(2-229)$ & 74 & $(8-192)$ & 908 & $(0-4464)$ \\
\hline $\begin{array}{l}\text { Convenant- } \\
\text { periode }\end{array}$ & \multicolumn{2}{|c|}{ Duur (dagen) a) } & \multicolumn{2}{|c|}{$\begin{array}{l}\text { Gedetecteerde } \\
\text { bedrijven }\end{array}$} & \multicolumn{2}{|c|}{$\begin{array}{l}\text { Preventief geruimde } \\
\text { koppels }\end{array}$} & \multicolumn{2}{|c|}{$\begin{array}{l}\text { Gevaccineerde } \\
\text { koppels }\end{array}$} \\
\hline 2015-2019 b) & 24 & $(4-65)$ & 14 & $(4-49)$ & 25 & $(8-53)$ & 382 & $(66-1165)$ \\
\hline
\end{tabular}

In grijs de resultaten voor heel Nederland, wat wil zeggen introductie in Nederland ongeacht lokale bedrijfsdichtheid. a) duur: periode tussen eerste en laatste detectie; b) resultaten uit Van Asseldonk et al (2014).

\subsubsection{Omvang uitbraken HPAI}

De epidemiologische resultaten voor HPAI zijn samengevat in tabel 3.4. Na een upgrade van het model voor HPAI is het aantal DPLA ten opzichte van SPLA-bedrijven voor HPAI sterk omlaaggegaan ten opzichte van de berekeningen voor de vorige convenantperiode. Het percentage DPLA-bedrijven is nu ongeveer $4 \%$ van het totaal aan pluimveebedrijven. $\mathrm{Er}$ is hierdoor een kleinere kans op insleep in DPLA en komen grote epidemieën minder vaak voor dan in de berekeningen voor de vorige convenantperiode en is de voorspelde omvang van grote epidemieën beperkter. Hierdoor is de mediaan voor heel Nederland van uitbraakduur en -grootte aanmerkelijk lager ten opzichte van de eerdere berekeningen. De voorspelde mediaan voor het aantal preventief geruimde bedrijven is zelfs meer dan tienmaal zo klein (nu 9, was 113). 
Tabel 3.4 Resultaten (mediaan en (5\%-95\%) interval) voor duur HPAI-epidemie en aantallen betrokken bedrijven, vergeleken met eerdere resultaten voor 2015-2019

\begin{tabular}{|c|c|c|c|}
\hline Convenant-periode & Duur (dagen) a) & Gedetecteerde bedrijven & $\begin{array}{l}\text { Preventief geruimde } \\
\text { bedrijven }\end{array}$ \\
\hline $2020-2024$ & $(0-29)$ & $(1-11)$ & $(0-52)$ \\
\hline DPPA & $(0-77)$ & $(3-29)$ & $(14-144)$ \\
\hline Convenant-periode & Duur (dagen) a) & Gedetecteerde bedrijven & $\begin{array}{l}\text { Preventief geruimde } \\
\text { bedrijven }\end{array}$ \\
\hline 2015-2019 b) & $(0-64)$ & $(1-71)$ & $(3-375)$ \\
\hline SPPA & $(0-51)$ & $(1-22)$ & $(0-186)$ \\
\hline MPPA & $(0-77)$ & $(1-84)$ & $(3-564)$ \\
\hline DPPA & $(0-80)$ & $(1-200)$ & $(10-646)$ \\
\hline
\end{tabular}

In grijs de resultaten voor heel Nederland, wat wil zeggen introductie in Nederland ongeacht lokale bedrijfsdichtheid. a) duur: periode tussen eerste en laatste detectie, b) resultaten uit Van Asseldonk et al. (2014). 


\section{$4 \quad$ Economische gevolgen}

\subsection{Aanpak berekeningen economische gevolgen}

Voor iedere sector wordt een kansverdeling voor de komende convenantperiode van vijf jaar berekend van de door het DGF gefinancierde bestrijdingskosten middels stochastische simulatie (conform eerder studies Van Asseldonk et al., 2009 en Van Asseldonk et al., 2014). De resultaten van de epidemiologische analyses, zoals beschreven in Hoofdstuk 3 (schatten van introductiekansen) en Hoofdstuk 4 (de epidemiologische gevolgen van een uitbraak), vormen de basis voor de economische berekeningen. De verwachte schades zijn herijkt omdat onder meer rekening is gehouden met de veranderde waarde van de dieren gebaseerd op de waardetabellen, afname van bedrijfsaantallen, toename van de bedrijfsgrootte, verschillen in bedrijfsgrootte in de verschillende gebieden en beperkte ruimingscapaciteit. Daarnaast heeft er een update van de epidemiologische modellen naar de effecten van de veranderde structuur van de sectoren (aantal bedrijven, bedrijfsomvang en contacten).

\subsection{Uitgangspunten bestrijdingskosten inclusief organisatiekosten}

In de terminologie van de kostenoverzichten zoals die door het ministerie van LNV gemaakt worden in verband met uitbraken van besmettelijke dierziekten, heeft het huidige onderzoek betrekking op de bestrijdingskosten. ${ }^{8}$ In tabel 4.1 zijn de bedragen die gebruikt worden voor het berekenen van de bestrijdingskosten van KVP, MKZ en AI die direct toe te rekenen zijn aan geruimde bedrijven samengevat. Gebruikte bronnen voor de uitgangspunten van de bestrijdingskosten zijn:

- Waardetabellen van de afgelopen vijf jaar zoals opgesteld door Wageningen Economic Research en kortgesloten met de sector;

- Kostenoverzichten van RVO inzake AI-bestrijdingskosten in de afgelopen vijf jaar;

- Afgesloten contracten van het ministerie van LNV (onder meer vaccin, ruiming en destructie);

- Kostenoverzichten afkomstig uit de jaarverslagen van het diergezondheidsfonds en aannames gebruikt voor vorige convenantberekeningen. Indexatie van de afrekening van grote uitbraken van MZK, KVP en AI.

De aannames zijn afgestemd met beleidsmedewerkers (ministerie van LNV en RVO) en vertegenwoordigers van de verschillende sectoren.

\footnotetext{
8 Convenant financiering bestrijding besmettelijke dierziekten LNV - PVV - PPE - PZ 2010 -2014 van 29 juni 2010, nr. 123215. [Online]. https://zoek.officielebekendmakingen.nl/stcrt-2010-11754.html.
} 
Tabel 4.1 Uitgangspunten bestrijdingskosten KVP, MKZ en AI direct toe te rekenen aan geruimde bedrijven

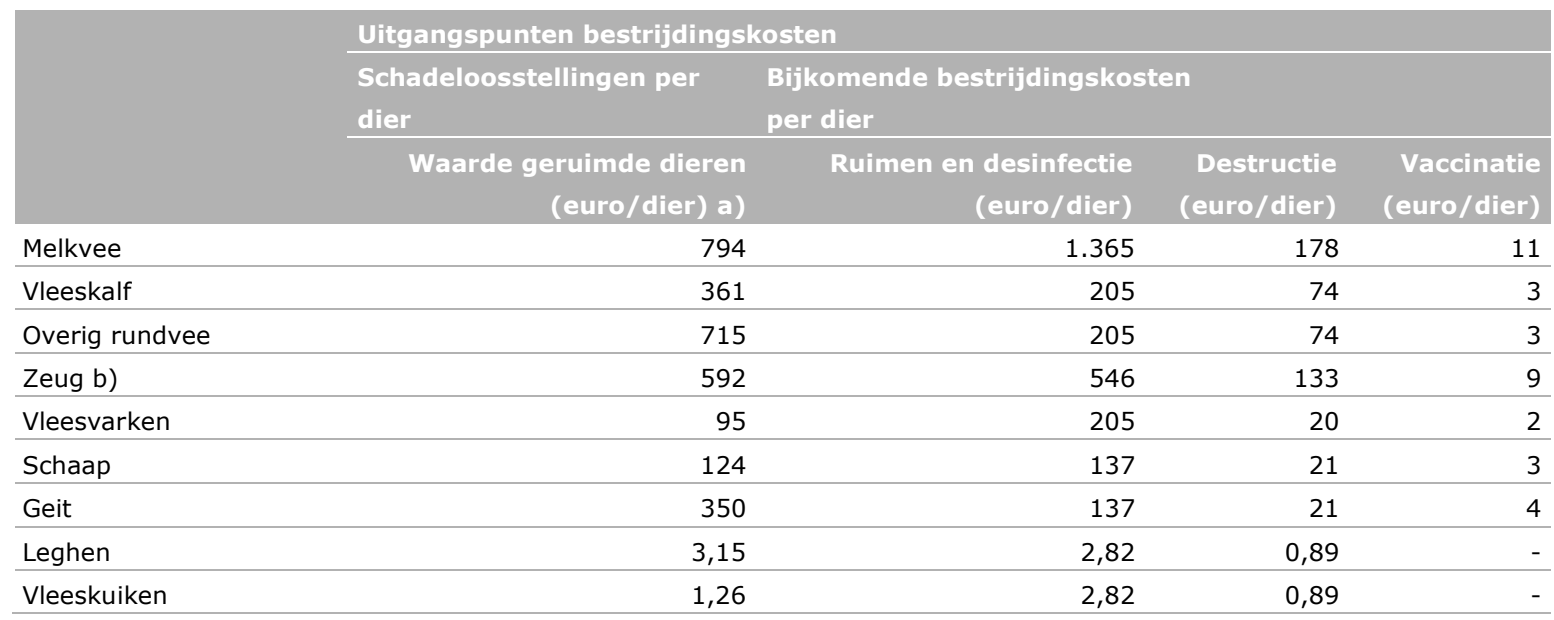

a) Schadeloosstelling voer, producten en materialen varieert tussen $5 \%$ en $10 \%$ van waarde geruimde dieren zoals berekend uit historische uitbraken; b) Inclusief gemiddeld aantal aanwezige biggen per zeug.

In tabel 4.2 zijn de taxatie- en screeningskosten weergegeven als ook de organisatiekosten. Dit zijn kosten die voor de bestrijding als geheel gemaakt moeten worden. Onderdeel van de organisatiekosten zijn bijvoorbeeld het handhaven van vervoersverboden. De begrote organisatiekosten omvatten alleen die activiteiten die niet door het reguliere personeel van het ministerie van LNV, RVO of NVWA uitgevoerd worden.

Bij een uitbraak zijn naast de bedrijven die bedrijfsmatig dieren houden ook veel hobbybedrijven met bestrijdingsmaatregelen betrokken. De kosten voor de bestrijding op deze bedrijven kwamen in het vorige convenant voor rekening van de overheid. In de berekeningen is ervan uitgegaan dat dit zo blijft in het nieuwe convenant. Om de organisatiekosten toe te kunnen rekenen aan de verschillende sectoren is een verdeelsleutel toegepast. Bij de verdeelsleutel is rekening gehouden met het feit dat hobbydieren niet onder het convenant vallen. Voor MKZ-uitbraken zijn deze bedragen verdeeld over de varkens-, runder- en schapen-/geitensector en hobbysector volgens een verhouding 4:4:1:1. ${ }^{9}$ In de berekeningen voor het DGF zijn dan ook 9/10 van deze kosten meegenomen.

Voor de berekeningen van de verwachte organisatiekosten bij KVP en MKZ zijn dezelfde bedragen gebruikt als voor AI. De organisatiekosten zijn echter bij KVP in het geheel aan de varkenssector toegerekend; het aantal hobbybedrijven met varkens is veel lager dan het aantal hobbybedrijven met geiten en/of schapen. De organisatiekosten zijn geschat op basis van recente AI-uitbraken. De verwachting is dat de recente organisatiekosten een beter beeld geven over de efficiëntere wijze waarop de overheid de bestrijding momenteel organiseert (op basis van onder meer reeds afgesloten contracten met bedrijfsleven) en het feit dat grote uitbraken met navenant hoge crisiscentrumkosten in de toekomst zeldzamer worden. Ook voor taxatie en screeningkosten is geen verschil gemaakt tussen de sectoren (hebben met name betrekking op inzet van arbeid). ${ }^{10}$

Tabel 4.2 Bijkomende bestrijdingskosten KVP, MKZ en AI

\begin{tabular}{ll} 
& Bedrag (euro) \\
Organisatiekosten & 101.286 euro/geïnfecteerd bedrijf \\
\hline Taxeren & 1.576 euro/geruimd bedrijf \\
\hline Screenen & 598 euro/bedrijf in BT gebied \\
\hline
\end{tabular}

\footnotetext{
9 De verhouding 4:4:1:1 is conform de berekeningen voorgaande convenant perioden en opgesteld door toenmalige betrokken productschappen.

${ }^{10}$ In de vorige berekening was voor zowel KVP, MKZ en AI een bedrag van 2,7 mln. euro per week aangenomen op basis van de MKZ-uitbraak in 2001 en HPAI-uitbraak in 2003.
} 


\section{Bijdrage EU Veterinair Fonds}

Volgens EU Council Decision 2009/470/EC draagt de EU bij aan de preventie, bestrijding en controle van uitbraken van besmettelijke dierziekten. In de berekeningen van kansverdeling van de door het DGF gefinancierde bestrijdingskosten is rekening gehouden met deze EU-bijdrage. Bij de eindafrekeningen van vorige grote uitbraken bleek dat bijvoorbeeld $36 \%$ en $33 \%$ bij respectievelijk de MKZ-uitbraak in 2001 en AI-uitbraak in 2003 van de totale bestrijdingskosten die onder het DGFconvenant vallen door de EU vergoed zijn. In lijn met vorige onderbouwingen is wederom uitgegaan dat $35 \%$ van de totale bestrijdingskosten die onder het convenant vallen door de EU vergoed worden.

\subsection{Verwachte kosten van besmettelijke dierziektenuitbraken}

Op basis van voorgaande aannames zijn in tabel 4.3 de gemiddelde schades per uitbraak en per bedrijfsdichtheidgebied weergeven. Het blijkt dat in geval van een MKZ-uitbraak de bestrijdingskosten het grootst zijn in de rundveehouderij en de varkenshouderij. De verwachte schade per uitbraak is aanzienlijk hoger voor insleep in bedrijfsdichte gebieden (DPLA) dan in bedrijfsarme gebieden (SPLA), wat het gevolg is van hogere aantallen besmettingen (tabel 4.3).

Voor de varkenssector leidt een uitbraak van KVP tot hogere bestrijdingskosten dan een uitbraak van MKZ. Dit komt mede doordat bij een uitbraak van KVP de bijkomende bestrijdingskosten niet over meerdere sectoren verdeeld kunnen worden. Ook de gemiddelde schadeomvang van een AI-uitbraak in een veedichtgebied is aanzienlijk.

Tabel 4.3 Meest waarschijnlijke schade (en 5\%-95\% interval) per uitbraak van MKZ, KVP- en AI a)

\begin{tabular}{|c|c|c|c|c|c|}
\hline & & \multicolumn{4}{|c|}{ Schade (in mln. euro) b) } \\
\hline & MKZ & & & KVP & AI \\
\hline DPLA & $15(0-44)$ & $37(3-132)$ & $1(0-3)$ & $22(5-60)$ & $17(4-34)$ \\
\hline \multicolumn{6}{|c|}{ DGF 2015-2019 } \\
\hline & MKZ & & & KVP & AI \\
\hline & Varkenshouderij & Rundveehouderij & $\begin{array}{l}\text { Schapen- en } \\
\text { geitenhouderij }\end{array}$ & Varkenshouderij & Pluimveehouderij \\
\hline SPLA & 2 & 7 & 1 & 16 & 14 \\
\hline
\end{tabular}

a) DPLA: bedrijfsdichte gebieden, MPLA: gemiddelde gebieden, SPLA: bedrijfsarme gebieden. Intervallen zijn niet berekend bij vorige convenantrapportage; b) Totale DGF-bestrijdingskosten die onder het convenant exclusief EU-vergoeding.

De verwachte bestrijdingskosten gedurende de convenantperiode 2020/2024 zijn vergeleken met de situatie in 2015/2019. De verwachte schadeafnamen worden met name veroorzaakt door de veranderde structuur van de sectoren (aantal bedrijven, bedrijfsomvang en contacten) en lagere organisatiekosten.

\subsection{Kansverdeling van schadebedragen}

In een vijfjaarlijkse convenantperiode kunnen geen, één of meerdere uitbraken optreden. Voor de het krijgen van inzicht in de verdeling van de schadebedragen wordt rekening gehouden met variatie en onzekerheid. Door het herhalen van de berekeningen (in het huidige onderzoek 10.000 iteraties) is het 
mogelijk om de variatie (en onzekerheid) van de input weerspiegeld te zien in de uitkomsten. Op deze manier wordt niet alleen de gemiddeld te verwachten uitkomst zichtbaar maar ook de variatie daaromheen, inclusief de extremen. De uitkomsten worden vooral bepaald door de kans van insleep en omvang van een uitbraak. Vervolgens wordt de totale schade per vijfjaarlijkse periode bepaald.

De schades worden weergegeven met behulp van de gemiddelde schade en kans-intervallen. Doordat de verwachte schades tussen de verschillende veehouderijsectoren sterk verschillen zijn de intervallen sector afhankelijk gemaakt. Zo zijn deze intervallen $10 \mathrm{mln}$. euro voor de varkenssector, $5 \mathrm{mln}$. voor de rundveesector, $1 \mathrm{mln}$. euro voor de schapen- en geitensector en $50 \mathrm{mln}$. voor de pluimveesector. Vervolgens worden de schades en hun kansen weergegeven als functie van het plafondbedrag. Aan de hand van de weergegeven relatie kan voor ieder willekeurig plafondbedrag de verwachte overheidsbijdrage en sectorbijdrage per 5 jaar (in mln. euro en in \%) worden bepaald. De gemodelleerde kansverdelingen van de bestrijdingskosten per sector gedurende de convenantperiode 2020/2024 worden vergeleken met de situatie in 2015/2019 (en op hoofdlijnen met de eerdere twee perioden).

\subsubsection{Varkenshouderij}

Door uitbraken van MKZ en/of KVP in de varkenshouderij is de verwachte schade gedurende de gehele periode 2020/2024, rekening houdend met een EU-compensatie van $35 \%$ van de bestrijdingskosten, $3,12 \mathrm{mln}$. euro (tabel 4.4). De kans op helemaal geen schade (er zijn geen uitbraken van zowel MKZ als KVP) in de komende convenantperiode is $50 \%$. Er is een kans van $41 \%$ dat er een schade optreedt gedurende de convenantperiode door een uitbraak van MKZ en/of KVP waarbij de schade ligt tussen de 0 en $10 \mathrm{mln}$. euro. $8 \%$ van de schades ligt tussen 10 en $40 \mathrm{mln}$. De kans dat de schade hoger is dan $40 \mathrm{mln}$. euro is zeer gering.

In vergelijking met de vorige studie voor periode $2015 / 2019$ is de verwachte schadelast in de varkenshouderij aanzienlijk afgenomen. De belangrijkste oorzaken hiervoor zijn de lagere kans op uitbraken (van 1 per 10 naar 1 per 15 voor zowel MKZ als KVP) en de effecten van de veranderde structuur van de sector (aantal bedrijven, bedrijfsomvang en contacten) met daarmee gepaard gaande beperktere verspreiding en dus minder extreme uitbraken. De verwachtingswaarde was $13 \mathrm{mln}$. euro per 5 jaar in 2015/2019 (tabel 4.4), $15 \mathrm{mln}$. euro per 5 jaar in 2010/2014 en $75 \mathrm{mln}$. euro per 5 jaar in 2005/2009. Het grote verschil tussen 2010/2014 en 2005/2009 werd veroorzaakt door wijziging van bestrijdingsstrategie van vaccinatie in plaats van ruimen. De kans dat géén schade optreedt in een periode van 5 jaar was 40\% per 5 jaar in 2015/2019 (tabel 4.4), 36\% in 2010/2014 en $13 \%$ in $2005 / 2009$.

Tabel 4.4 Kans per kosteninterval en gemiddelde kosten per 5 jaar voor de varkenshouderij

\begin{tabular}{lll} 
& $2020 / 2024$ & \\
Kosteninterval & Kans & Kans \\
(mln. euro) & $(\%)$ & $(\%)$ \\
\hline 0 & 50 & 40 \\
\hline $0-10$ & 41 & 29 \\
\hline $10-20$ & 5 & 11 \\
\hline $20-30$ & 2 & 8 \\
\hline $30-40$ & 1 & 4 \\
\hline $40-50$ & 0 & 2 \\
\hline$>50$ & 0 & 7 \\
\hline Totaal & 100 & 100 \\
\hline Gemiddelde kosten (mln. euro) & 3,12 & 13 \\
\hline
\end{tabular}

Op basis van de beschreven wijzigingen is voor verschillende kostenintervallen de verdeling van de bestrijdingskosten tussen overheid en sector berekend. In figuur 4.1 zijn de resultaten van verschillende kostenintervallen weergegeven. Aan de hand van de weergegeven relatie kan voor ieder 
willekeurig plafondbedrag de verwachte overheidsbijdrage per 5 jaar (in mln. euro) en de kans dat de overheid een bijdrage levert per 5 jaar (in \%) afgelezen worden.

Ter illustratie het volgende voorbeeld: bij een plafond van $10 \mathrm{mln}$. euro voor de varkenshouderij (horizontale as of tabel) valt af te lezen op de verticale as dat de verwachte overheidsbijdrage circa $1,19 \mathrm{mln}$. euro bedraagt. De verwachte bijdrage van de sector is dan 1,93 $\mathrm{mln}$. euro $(3,12 \mathrm{mln}$. euro verwachte schade minus $1,19 \mathrm{mln}$. euro). Verder blijkt dat de overschrijdingskans circa $9 \%$ bedraagt bij een plafond van $10 \mathrm{mln}$. euro.

\subsubsection{Rundveehouderij}

De verwachte schade gedurende de periode 2020/2024, rekening houdend met een EU-compensatie van $35 \%$ van de bestrijdingskosten, bedraagt 2,89 $\mathrm{mln}$. euro in de rundveehouderij door een uitbraak van MKZ (tabel 4.5). Verder blijkt bijvoorbeeld dat de kans op helemaal geen schade in de convenantperiode $71 \%$ bedraagt. Er is een kans van $16 \%$ dat er een schade optreedt gedurende de convenantperiode door een uitbraak van MKZ waarbij de schade ligt tussen de 0 en $10 \mathrm{mln}$. euro. De kans dat de schade hoger is dan $25 \mathrm{mln}$. euro is $2 \%$.

In vergelijking met de vorige studie voor periode $2015 / 2019$ is de verwachte schadelast in de rundveehouderij aanzienlijk afgenomen door veranderde inzichten in de kansen van uitbraken (van 1 per 10 naar 1 per 15 voor MKZ) en de effecten van de veranderde structuur van de sector (aantal bedrijven, bedrijfsomvang en contacten). De verwachtingswaarde was $9 \mathrm{mln}$. euro per 5 jaar in 2015/2019 (tabel 4.5), 6 mln. euro per 5 jaar in 2010/2014 en $10 \mathrm{mln}$. euro per 5 jaar in 2005/2009. De kans dat géén schade optreedt in een periode van 5 jaar was 61\% per 5 jaar in 2015/2019 (Tabel 14), 59\% in 2010/2014 en $37 \%$ in 2005/2009.

Tabel 4.5 Kans per kosteninterval en gemiddelde kosten per 5 jaar voor de rundveehouderij

\begin{tabular}{lll} 
& $2020 / 2024$ & \\
Kosteninterval & Kans & Kans \\
(mln. euro) & $(\%)$ & $(\%)$ \\
\hline 0 & 71 & 61 \\
\hline $0-5$ & 16 & 13 \\
\hline $5-10$ & 6 & 7 \\
\hline $10-15$ & 3 & 3 \\
\hline $15-20$ & 1 & 2 \\
\hline $20-25$ & 1 & 2 \\
\hline$>25$ & 2 & 12 \\
\hline Totaal & 100 & 100 \\
\hline Gemiddelde kosten (mln. euro) & 2,89 & 9 \\
\hline
\end{tabular}

Op basis van de wijzigingen zoals gerapporteerd in de voorgaande paragrafen is voor verschillende kostenintervallen de verdeling van de bestrijdingskosten tussen overheid en sector herijkt. In figuur 4.2 zijn de resultaten van verschillende kostenintervallen weergegeven. Aan de hand van de weergegeven relatie kan voor ieder willekeurig plafondbedrag de verwachte overheidsbijdrage per 5 jaar (in mln. euro) en de kans dat de overheid een bijdrage levert per 5 jaar (in \%) afgelezen worden.

Ter illustratie het volgende voorbeeld: bij een plafond van $10 \mathrm{mln}$. euro voor de rundveehouderij (horizontale as of tabel) valt af te lezen op de verticale as dat de verwachte overheidsbijdrage circa $1,39 \mathrm{mln}$. euro bedraagt. De verwachte bijdrage van de sector is dan $1,50 \mathrm{mln}$. euro $(2,89 \mathrm{mln}$. euro verwachte schade minus $1,39 \mathrm{mln}$. euro). Verder blijkt dat bij een plafond van $10 \mathrm{mln}$. euro de overschrijdingskans circa $7 \%$ bedraagt. 

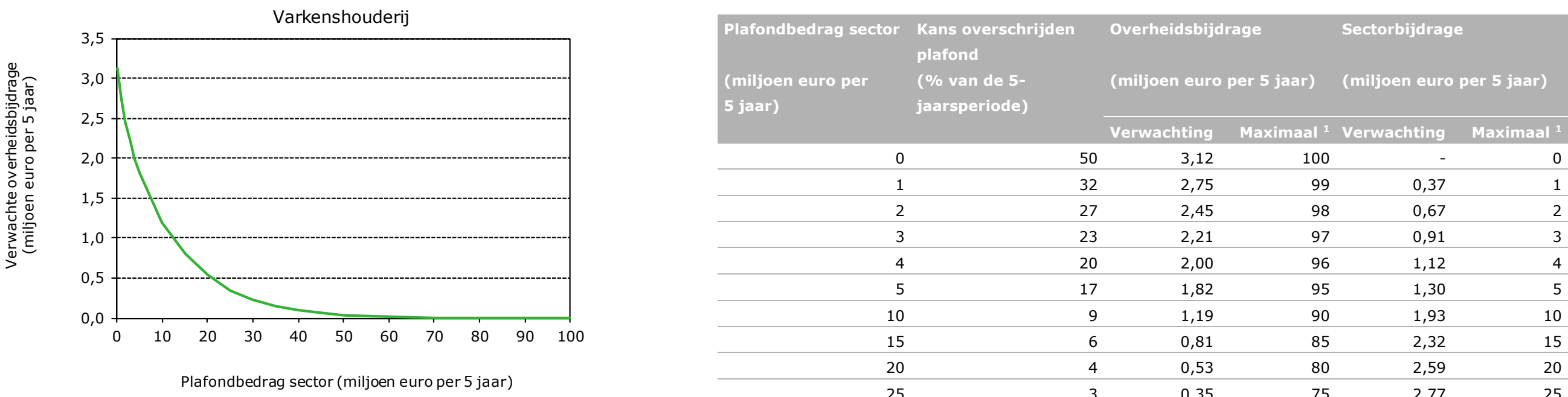

\begin{tabular}{rrrrrr}
\hline 0 & 50 & 3,12 & 100 & - & 0 \\
\hline 1 & 32 & 2,75 & 99 & 0,37 & 1 \\
\hline 2 & 27 & 2,45 & 98 & 0,67 & 2 \\
\hline 3 & 23 & 2,21 & 97 & 0,91 & 3 \\
\hline 4 & 20 & 2,00 & 96 & 1,12 & 4 \\
\hline 5 & 17 & 1,82 & 95 & 1,30 & 5 \\
\hline 10 & 9 & 1,19 & 90 & 1,93 & 10 \\
\hline 15 & 6 & 0,81 & 85 & 2,32 & 15 \\
\hline 20 & 4 & 0,53 & 80 & 2,59 & 20 \\
\hline 25 & 3 & 0,35 & 75 & 2,77 & 25 \\
\hline 30 & 2 & 0,22 & 70 & 2,90 & 30 \\
\hline 35 & 1 & 0,14 & 65 & 2,98 & 35 \\
\hline 40 & 1 & 0,09 & 60 & 3,03 & 40 \\
\hline 45 & 1 & 0,06 & 55 & 3,06 & 45 \\
\hline 50 & 0 & 0,03 & 50 & 3,09 & 50 \\
\hline 60 & 0 & 0,01 & 40 & 3,11 & 60 \\
\hline 70 & 0 & 0,00 & 30 & 3,12 & 70 \\
\hline 80 & 0 & 0,00 & 20 & 3,12 & 80 \\
\hline 90 & 0 & 0,00 & 10 & 3,12 & 90 \\
\hline 100 & 0 & 0,00 & 0 & 3,12 & 100 \\
\hline
\end{tabular}

${ }^{1}$ Op basis van 10.000 @risk iteraties.

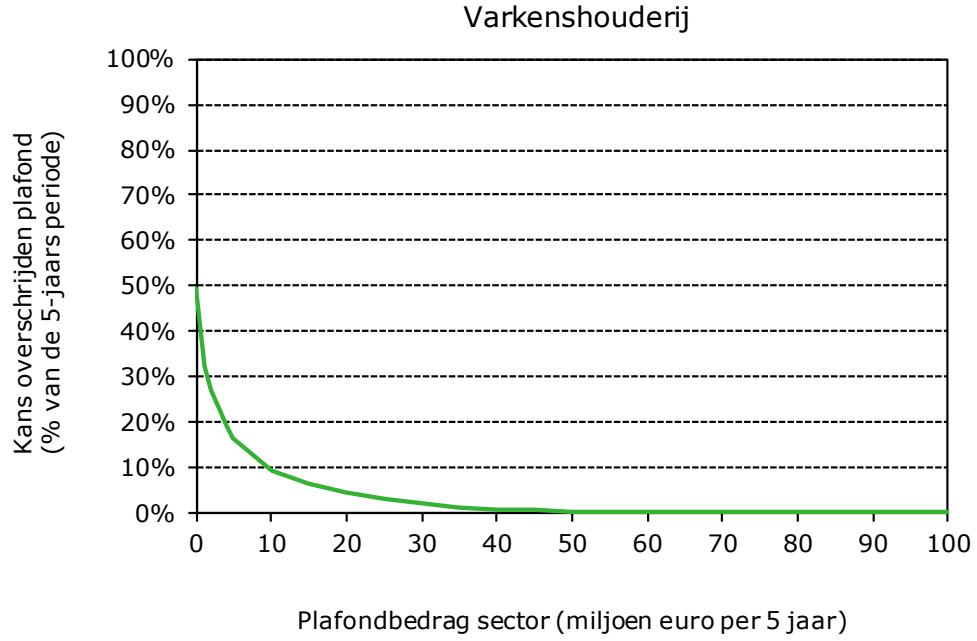

Figuur 4.1 Relatie plafondbedrag en overheidsbijdrage per 5 jaar in de varkenshouderij, zowel in mln. euro (boven) als in \% (onder) 

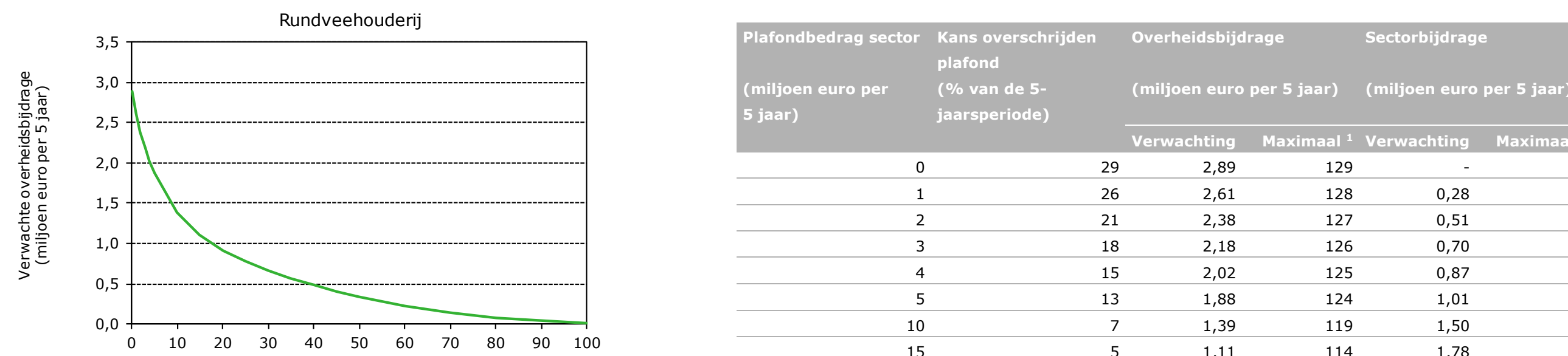

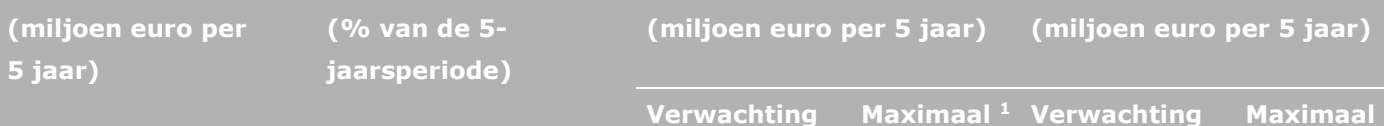

\begin{tabular}{rrrrrr}
0 & 29 & 2,89 & 129 & - & 0 \\
\hline 1 & 26 & 2,61 & 128 & 0,28 & 1 \\
\hline 2 & 21 & 2,38 & 127 & 0,51 & 2 \\
\hline 3 & 18 & 2,18 & 126 & 0,70 & 3 \\
\hline 4 & 15 & 2,02 & 125 & 0,87 & 4 \\
\hline 5 & 13 & 1,88 & 124 & 1,01 & 5 \\
\hline 10 & 7 & 1,39 & 119 & 1,50 & 10 \\
\hline 15 & 5 & 1,11 & 114 & 1,78 & 15 \\
\hline 20 & 3 & 0,91 & 109 & 1,97 & 20 \\
\hline 25 & 2 & 0,77 & 104 & 2,11 & 25 \\
\hline 30 & 2 & 0,67 & 99 & 2,22 & 30 \\
\hline 35 & 2 & 0,57 & 94 & 2,31 & 35 \\
\hline 40 & 2 & 0,49 & 89 & 2,40 & 40 \\
\hline 45 & 1 & 0,41 & 84 & 2,48 & 45 \\
\hline 50 & 1 & 0,34 & 79 & 2,55 & 50 \\
\hline 60 & 1 & 0,22 & 69 & 2,66 & 60 \\
\hline 70 & 1 & 0,14 & 59 & 2,74 & 70 \\
\hline 80 & 1 & 0,08 & 49 & 2,80 & 80 \\
\hline 90 & 0 & 0,04 & 39 & 2,84 & 90 \\
\hline 100 & 0 & 0,02 & 29 & 2,87 & 100 \\
\hline
\end{tabular}

${ }^{1}$ Op basis van 10000 @risk iteraties.

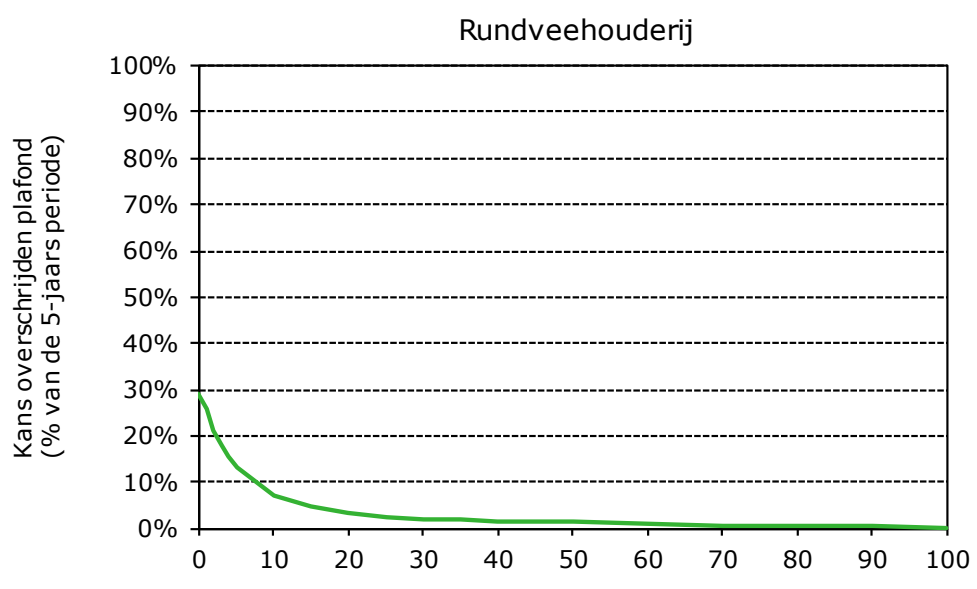

Plafondbedrag sector (miljoen euro per 5 jaar)

Figuur 4.2 Relatie plafondbedrag en overheidsbijdrage per 5 jaar in de rundveehouderij, zowel in mln. euro (boven) als in \% (onder). 


\subsubsection{Schapen- en geitenhouderij}

De verwachte schade gedurende de periode 2020/2024, rekening houdend met een EU compensatie van $35 \%$ van de bestrijdingskosten, bedraagt $0,15 \mathrm{mln}$. euro voor de schapen- en (melk)geitenhouderij gezamenlijk door een uitbraak van MKZ (tabel 4.6). Verder blijkt bijvoorbeeld dat de kans op helemaal geen schade in de convenantperiode $71 \%$ bedraagt. Er is een kans van $25 \%$ dat er een schade optreedt gedurende de convenantperiode door een uitbraak van MKZ waarbij de schade ligt tussen de 0 en $1 \mathrm{mln}$. euro. De kans dat de schade hoger is dan $2 \mathrm{mln}$. euro is gering. Een verdere uitsplitsing per sector is nader uitgewerkt in tabel B1.1 en tabel B1.2 in bijlage 1 voor respectievelijk de schapenhouderij en de (melk)geitenhouderij.

In vergelijking met de vorige studie voor periode $2015 / 2019$ is de verwachte schadelast in de schapen- en geitenhouderij verder afgenomen door de lagere kans op uitbraken (van 1 per 10 naar 1 per 15 voor $M K Z$ ) en de effecten van de veranderde structuur van de sector (aantal bedrijven, bedrijfsomvang en contacten). De verwachtingswaarde was 0,49 mln. euro per 5 jaar in 2015/2019 (tabel 4.6), 0,98 mln. euro per 5 jaar in 2010/2014 en 1,5 mln. euro per 5 jaar in 2005/2009. De kans dat géén schade optreedt in een periode van 5 jaar was $61 \%$ per 5 jaar in 2015/2019 (tabel 4.6), 59\% in 2010/2014 en 37\% in 2005/2009. De kans dat er geen schade optreedt ten gevolge van MKZ in schapen- en geitensector is gelijk aan de kans dat er geen schade optreedt in de rundveesector.

Tabel 4.6 Kans per kosteninterval en gemiddelde kosten per 5 jaar voor de schapen- en geitenhouderij.

\begin{tabular}{lll} 
& $2020 / 2024$ & \\
Kosteninterval & Kans & Kans \\
(mln. euro) & $(\%)$ & $(\%)$ \\
\hline 0 & 71 & 61 \\
\hline $0-1$ & 25 & 20 \\
\hline $1-2$ & 3 & 9 \\
\hline $2-3$ & 0 & 5 \\
\hline $3-4$ & 0 & 3 \\
\hline $4-5$ & 0 & 1 \\
\hline$>5$ & 0 & 1 \\
\hline Totaal & 100 & 100 \\
\hline Gemiddelde kosten (mln. euro) & 0,15 & 0,49
\end{tabular}

Op basis van de wijzigingen zoals gerapporteerd in de voorgaande paragrafen is voor verschillende kostenintervallen de verdeling van de bestrijdingskosten tussen overheid en sector berekend. In Figuur 4.3 zijn de resultaten van verschillende kostenintervallen weergegeven. Aan de hand van de weergegeven relatie kan voor ieder willekeurig plafondbedrag de verwachte overheidsbijdrage per 5 jaar (in mln. euro) en de kans dat de overheid een bijdrage levert per 5 jaar (in \%) afgelezen worden.

Ter illustratie het volgende voorbeeld: bij een plafond van 0,5 mln. euro voor de schapen- en geitenhouderij (horizontale as of tabel) valt af te lezen op de verticale as dat de verwachte overheidsbijdrage circa 0,06 $\mathrm{mln}$. euro bedraagt. De verwachte bijdrage van de sector is dan $0,09 \mathrm{mln}$. euro $(0,15 \mathrm{mln}$. euro verwachte schade minus 0,06 mln. euro). Verder blijkt dat de overschrijdingskans circa $8 \%$ bedraagt bij een plafond van $0,5 \mathrm{mln}$. euro. Een verdere uitsplitsing voor de schapen en geitensector afzonderlijk is nader uitgewerkt in bijlage 2 .

\subsubsection{Pluimveehouderij}

De verwachte schade gedurende de periode 2020/2024, rekening houdend met een EU-compensatie, bedraagt $36 \mathrm{mln}$. euro in de pluimveehouderij door een uitbraak van AI (tabel 16). De kans op helemaal geen schade in de convenantperiode is zeer gering. Er is een kans van $78 \%$ dat er een 
schade optreedt gedurende de convenantperiode door een uitbraak van AI waarbij de schade ligt tussen de 0 en $50 \mathrm{mln}$. euro. De kans op zeer grote schades, hoger is dan $100 \mathrm{mln}$. euro, is $1 \%$.

In vergelijking met de vorige studie voor periode 2015/2019 is de verwachte schadelast in de pluimveehouderij min of meer gelijk gebleven. De toegenomen kans van een uitbraak gaat gepaard met een kleinere omvang van een uitbraak. De verwachtingswaarde was $35 \mathrm{mln}$. euro per 5 jaar in 2015/2019 (tabel 4.7), $32 \mathrm{mln}$. euro per 5 jaar in 2010/2014 en $52 \mathrm{mln}$. euro per 5 jaar in 2005/2009. De kans dat géén schade optreedt in een periode van 5 jaar was $37 \%$ per 5 jaar in 2015/2019 (tabel 4.7) evenals in 2010/2014 en 2005/2009.

Tabel 4.7 Kans per kosteninterval en gemiddelde kosten per 5 jaar voor de pluimveehouderij.

\begin{tabular}{lll} 
Kosteninterval & $2020 / 2024$ & Kans \\
(mln. euro) & Kans & $(\%)$ \\
\hline 0 & $(\%)$ & 37 \\
\hline $0-50$ & 0 & 35 \\
\hline $50-100$ & 78 & 15 \\
\hline $100-150$ & 21 & 8 \\
\hline $150-200$ & 1 & 4 \\
\hline $200-250$ & 0 & 1 \\
\hline $250-300$ & 0 & 0 \\
\hline$>300$ & 0 & 0 \\
\hline Totaal & 0 & 100 \\
\hline Gemiddelde kosten (mln. euro) & 36 & 35 \\
\hline
\end{tabular}

Op basis van de wijzigingen zoals gerapporteerd in de voorgaande paragrafen is voor verschillende kostenintervallen de verdeling van de bestrijdingskosten tussen overheid en sector berekend. In figuur 4.4 zijn de resultaten van verschillende kostenintervallen weergegeven. Aan de hand van de weergegeven relatie kan voor ieder willekeurig plafondbedrag de verwachte overheidsbijdrage per 5 jaar (in mln. euro) en de kans dat de overheid een bijdrage levert per 5 jaar (in \%) afgelezen worden.

Ter illustratie het volgende voorbeeld: bij een plafond van $10 \mathrm{mln}$. euro voor de pluimveehouderij (horizontale as of tabel) valt af te lezen op de verticale as dat de verwachte overheidsbijdrage circa $26 \mathrm{mln}$. euro bedraagt. De verwachte bijdrage van de sector is dan $10 \mathrm{mln}$. euro (36 mln. euro verwachte schade minus $26 \mathrm{mln}$. euro). Verder blijkt dat de overschrijdingskans circa $93 \%$ bedraagt bij een plafond van $10 \mathrm{mln}$. euro. 
Schapen- en geitenhouderij

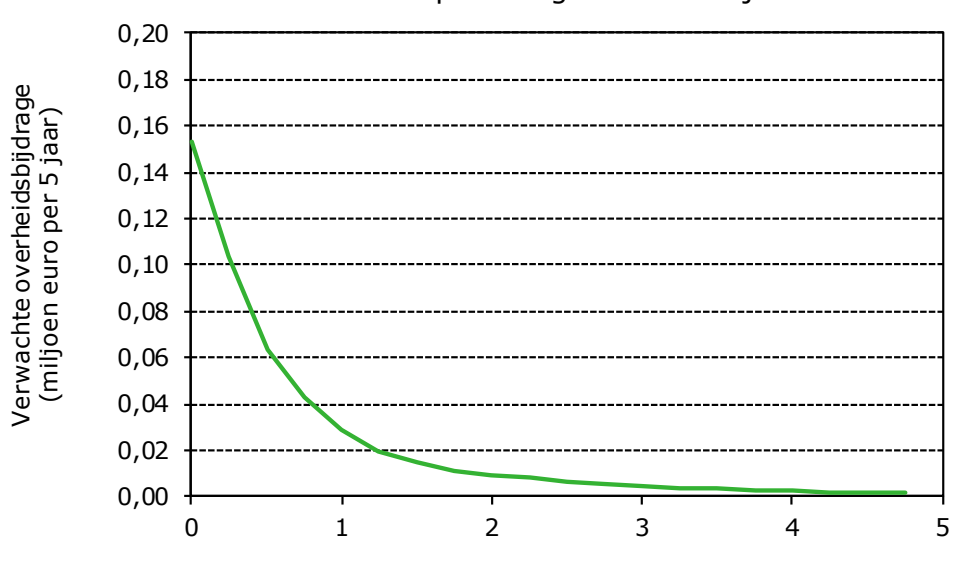

Plafondbedrag sector (miljoen euro per 5 jaar)

Schapen- en geitenhouderij

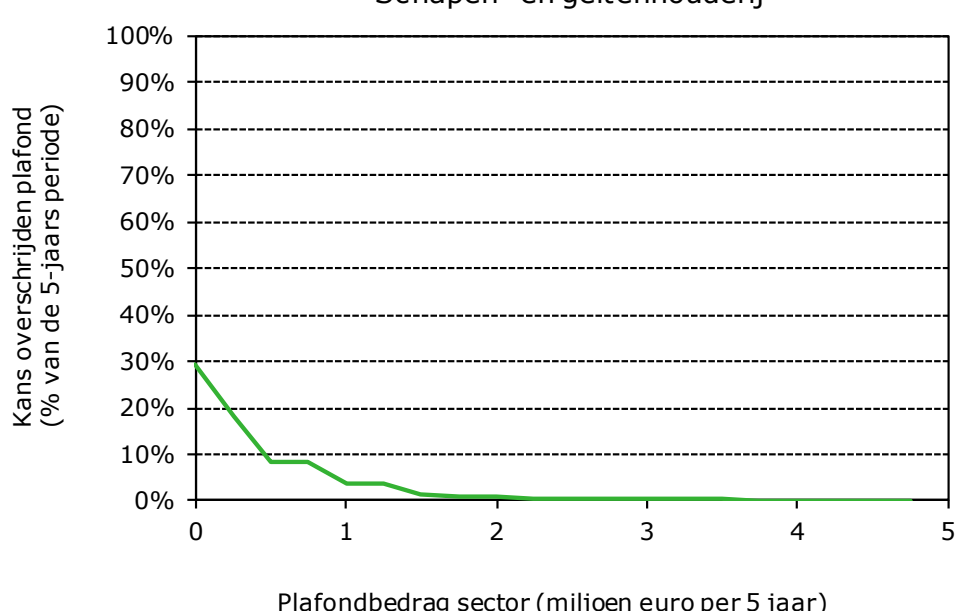

\begin{tabular}{|c|c|c|c|c|c|c|}
\hline \multirow{2}{*}{$\begin{array}{l}\text { Plafondbedrag sector } \\
\text { (miljoen euro per } \\
5 \text { jaar) }\end{array}$} & \multirow{2}{*}{\multicolumn{2}{|c|}{$\begin{array}{l}\text { Kans overschrijden } \\
\text { plafond } \\
\text { (\% van de } 5- \\
\text { jaarsperiode) }\end{array}$}} & \multicolumn{2}{|c|}{$\begin{array}{l}\text { Overheidsbijdrage } \\
\text { (miljoen euro per } 5 \text { jaar) }\end{array}$} & \multicolumn{2}{|c|}{$\begin{array}{l}\text { Sectorbijdrage } \\
\text { (miljoen euro per } 5 \text { jaar) }\end{array}$} \\
\hline & & & Verwachting & Maximaal $^{1}$ & Verwachting & Maximaal $^{1}$ \\
\hline- & & 29 & 0,15 & 8 & - & - \\
\hline 0,25 & & 9 & 0,10 & 8 & 0,05 & 0,25 \\
\hline 0,50 & & 8 & 0,06 & 8 & 0,09 & 0,50 \\
\hline 0,75 & & 4 & 0,04 & 8 & 0,11 & 0,75 \\
\hline 1,00 & & 4 & 0,03 & 7 & 0,12 & 1,00 \\
\hline 1,25 & & 2 & 0,02 & 7 & 0,13 & 1,25 \\
\hline 1,50 & & 1 & 0,01 & 7 & 0,14 & 1,50 \\
\hline 1,75 & & 1 & 0,01 & 7 & 0,14 & 1,75 \\
\hline 2,00 & & 1 & 0,01 & 6 & 0,14 & 2,00 \\
\hline 2,25 & & 0 & 0,01 & 6 & 0,15 & 2,25 \\
\hline 2,50 & & 0 & 0,01 & 6 & 0,15 & 2,50 \\
\hline 2,75 & & 0 & 0,01 & 6 & 0,15 & 2,75 \\
\hline 3,00 & & 0 & 0,00 & 5 & 0,15 & 3,00 \\
\hline 3,25 & & 0 & 0,00 & 5 & 0,15 & 3,25 \\
\hline 3,50 & & 0 & 0,00 & 5 & 0,15 & 3,50 \\
\hline 3,75 & & 0 & 0,00 & 5 & 0,15 & 3,75 \\
\hline 4,00 & & 0 & 0,00 & 4 & 0,15 & 4,00 \\
\hline 4,25 & & 0 & 0,00 & 4 & 0,15 & 4,25 \\
\hline 4,50 & & 0 & 0,00 & 4 & 0,15 & 4,50 \\
\hline 4,75 & & 0 & 0,00 & 4 & 0,15 & 4,75 \\
\hline
\end{tabular}

${ }^{1}$ Op basis van 10000 @risk iteraties.

Figuur 2.3 Relatie plafondbedrag en overheidsbijdrage per 5 jaar in de schapen- en geitenhouderij, zowel in mln. euro (boven) als in \% (onder) 

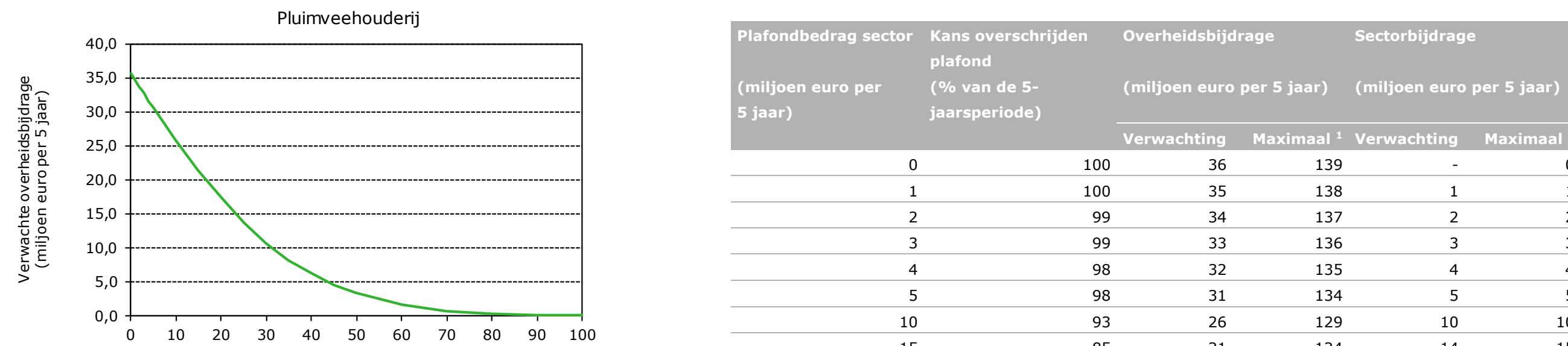

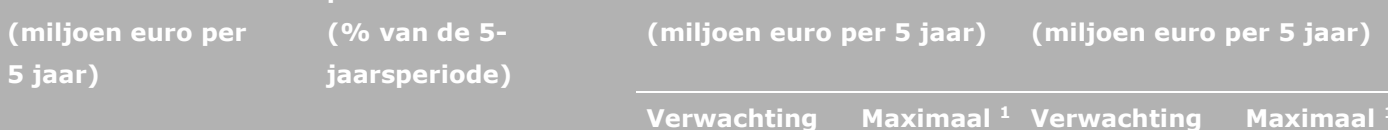

\begin{tabular}{rrrrrr}
\hline 0 & 100 & 36 & 139 & - & 0 \\
\hline 1 & 100 & 35 & 138 & 1 & 1 \\
\hline 2 & 99 & 34 & 137 & 2 & 2 \\
\hline 3 & 99 & 33 & 136 & 3 & 3 \\
\hline 4 & 98 & 32 & 135 & 4 & 4 \\
\hline 5 & 98 & 31 & 134 & 5 & 5 \\
\hline 10 & 93 & 26 & 129 & 10 & 10 \\
\hline 15 & 85 & 21 & 124 & 14 & 15 \\
\hline 20 & 76 & 17 & 119 & 18 & 20 \\
\hline 25 & 66 & 14 & 114 & 22 & 25 \\
\hline 30 & 56 & 11 & 109 & 25 & 30 \\
\hline 35 & 46 & 8 & 104 & 27 & 35 \\
\hline 40 & 36 & 6 & 99 & 29 & 40 \\
\hline 45 & 29 & 5 & 94 & 31 & 45 \\
\hline 50 & 22 & 3 & 89 & 32 & 50 \\
\hline 60 & 12 & 2 & 79 & 34 & 60 \\
\hline 70 & 6 & 1 & 69 & 35 & 70 \\
\hline 80 & 3 & 0 & 59 & 35 & 80 \\
\hline 90 & 1 & 0 & 49 & 35 & 90 \\
\hline 100 & 1 & 0 & 39 & 36 & 100 \\
\hline
\end{tabular}

${ }^{1}$ Op basis van 10000 @risk iteraties.

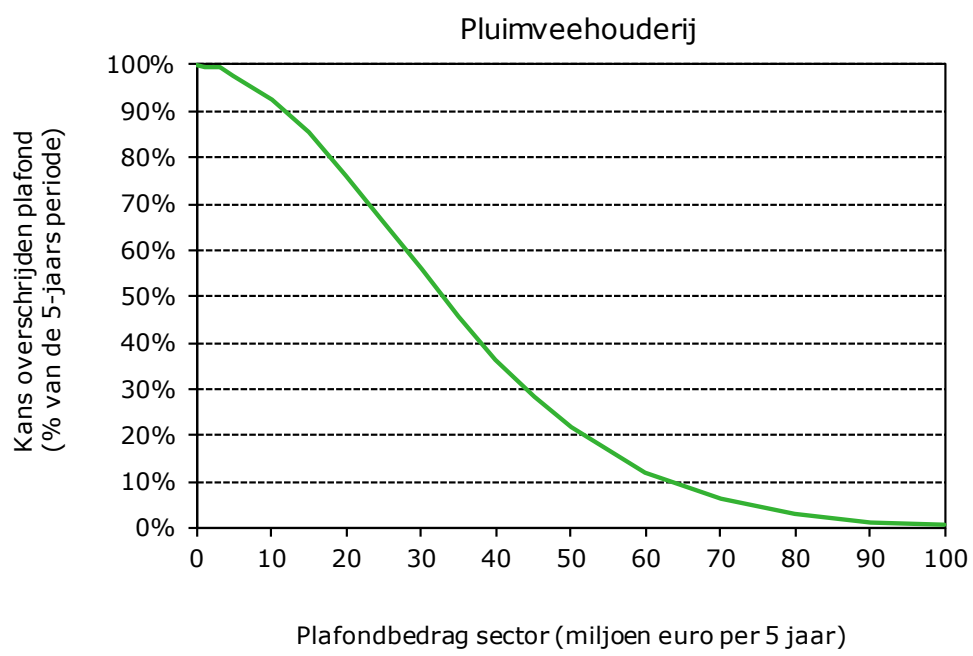

Figuur 4.4 Relatie plafondbedrag en overheidsbijdrage per 5 jaar in de pluimveehouderij, zowel in mln. euro (boven) als in \% (onder) 


\section{$5 \quad$ Conclusie}

De berekende verwachte DGF-bijdrage in de bestrijdingskosten voor MKZ en KVP is in de 2020/2024scenario's lager dan eerder berekend voor de periode 2015/2019. Verschillen met de eerder verrichte studie voor de periode 2015/2019 worden onder meer veroorzaakt door een lager ingeschatte kans op insleep voor KVP-en MKZ ( 1 per 15 jaar in plaats van 1 per 10 jaar). De verwachte MKZ- en KVPuitbraakomvang zijn vergelijkbaar met de eerdere resultaten uit het rapport voor de convenantperiode 2015-2019.

Voor AI is de DGF-bijdrage in de bestrijdingskosten min of meer gelijk gebleven aan de vorige convenantperiode. De kans op insleep is toegenomen maar de omvang van een uitbraak is beperkter. Voor de komende convenantperiode wordt namelijk de kans op een HPAI-seizoen van hoog-pathogene AI (HPAI) geschat op gemiddeld 0,75 per jaar ( 3 uit 4 seizoenen) en gemiddeld 5,33 uitbraken per HPAI-seizoen (16 afzonderlijke/onafhankelijke uitbraken in 3 seizoenen). Echter, voor HPAI is de voorspelde omvang van epidemieën beperkter dan voor de convenantperiode 2015-2019.

De gemiddelde DGF-bijdrage wordt geschat op:

- Voor de varkenshouderij 3,12 mln. euro per 5 jaar (13 $\mathrm{mln}$. euro in de vorige convenantperiode)

- Voor de rundveehouderij 2,89 $\mathrm{mln}$. euro per 5 jaar ( $9 \mathrm{mln}$. euro in de vorige convenantperiode)

- Voor de schapen- en geitenhouderij 0,15 mln. euro per 5 jaar $(0,49 \mathrm{mln}$. euro in de vorige convenantperiode),

- en voor de pluimveehouderij is dit $36 \mathrm{mln}$. euro per 5 jaar (35 $\mathrm{mln}$. euro in de vorige convenantperiode). 


\section{Literatuur en websites}

Asseldonk, M. van, J. Backer, A. Elbers, T. Hagenaars, N. Longworth, H. Saatkamp en R. Bergevoet, 2009. Omvang diergezondheidsfondsen 2010-2014. Intern LEI rapport 2009.

Asseldonk, M. van, J. Backer, A. Elbers, T. Hagenaars, G. Boender, R. Bergevoet, 2014. Onderbouwing DGF-plafonds ten behoeve van herijking het convenant: Financiering bestrijding besmettelijke dierziekten/DGF 2015-2019. Intern LEI rapport 2014.

Backer, J., R. Bergevoet, E. Fischer, G. Nodelijk, K. Bosman, H. Saatkamp en H. van Roermund, 2011. Control of highly pathogenic avian influenza : epidemiological and economic aspects. LEI Wageningen UR Den Haag.

Backer, J., T. Hagenaars, G. Nodelijk en H. van Roermund, 2012. Vaccination against foot-and-mouth disease I: Epidemiological consequences. Preventive Veterinary Medicine 107, 27-40.

Backer, J., T. Hagenaars, H. van Roermund en M. de Jong, 2009. Modelling the effectiveness and risks of vaccination strategies to control classical swine fever epidemics. Journal of The Royal Society Interface 6, 849-861.

Boender, G., T. Hagenaars, A. Bouma, G. Nodelijk, A. Elbers, M. de Jong en M. van Boven, 2007. Risk Maps for the Spread of Highly Pathogenic Avian Influenza in Poultry. PLoS Computational Biology 3, e71.

Boender, G., R. van den Hengel en H. van Roermund, T. Hagenaars, 2014. The Influence of BetweenFarm Distance and Farm Size on the Spread of Classical Swine Fever during the 1997-1998 Epidemic in The Netherlands. PLoS ONE 9(4): e95278.

Boender, G., H. van Roermund, M. de Jong en T. Hagenaars, 2010. Transmission risks and control of foot-and-mouth disease in The Netherlands: Spatial patterns. Epidemics 2, 36-47.

Gemeraad, E., N. Beerens en A. Elbers. Risicoanalyse voor de Nederlandse commerciële pluimveehouderij voor besmetting met hoog pathogeen aviair influenza virus. WBVR rapport augustus 2018.

Loeffen, W., 2018. Risicoanalyse voor introductie van Afrikaanse varkenspest in gehouden varkens en wilde zwijnen in Nederland. WBVR Rapport augustus 2018.

Vos, C. de, J. van der Goot, F. van Zijderveld, M. Swanenburg en A. Elbers, 2015. Risk-based testing of imported animals: A case study for bovine tuberculosis in The Netherlands. Preventive Veterinary Medicine 121: 8 -20. 


\section{Bijlage 1 Uitsplitsing schade schapenhouderij en geitenhouderij}

Tabel B1.1 Kans per kosteninterval en gemiddelde kosten per 5 jaar voor de schapenhouderij

\begin{tabular}{ll} 
Kosteninterval & $2020 / 2024$ \\
(mln. euro) & Kans \\
0 & $(\%)$ \\
\hline $0-1$ & 71 \\
\hline $1-2$ & 28 \\
\hline $2-3$ & 1 \\
\hline $3-4$ & 0 \\
\hline $4-5$ & 0 \\
\hline$>5$ & 0 \\
\hline Totaal & 0 \\
\hline Gemiddelde kosten (mln. euro) & 100 \\
\hline
\end{tabular}

Tabel B1.2 Kans per kosteninterval en gemiddelde kosten per 5 jaar voor de geitenhouderij

\begin{tabular}{ll} 
Kosteninterval & $2020 / 2024$ \\
(mln. euro) & Kans \\
\hline 0 & $(\%)$ \\
\hline $0-1$ & 71 \\
\hline $1-2$ & 28 \\
\hline $2-3$ & 1 \\
\hline $3-4$ & 0 \\
\hline $4-5$ & 0 \\
\hline$>5$ & 0 \\
\hline Totaal & 0 \\
\hline Gemiddelde kosten (mln. euro) & 100 \\
\hline
\end{tabular}




\section{Bijlage 2 Relatie plafondbedrag en overheidsbijdrage in de schapenhouderij en geitenhouderij}



\begin{tabular}{|c|c|c|c|c|c|c|}
\hline \multirow{2}{*}{$\begin{array}{l}\text { Plafondbedrag sector } \\
\text { (miljoen euro per } \\
5 \text { jaar) }\end{array}$} & \multirow{2}{*}{\multicolumn{2}{|c|}{$\begin{array}{l}\text { Kans overschrijden } \\
\text { plafond } \\
\text { (\% van de } 5- \\
\text { jaarsperiode) }\end{array}$}} & \multicolumn{2}{|c|}{$\begin{array}{l}\text { Overheidsbijdrage } \\
\text { (miljoen euro per } 5 \text { jaar) }\end{array}$} & \multicolumn{2}{|c|}{ Sectorbijdrage } \\
\hline & & & Verwachting & Maximaal ${ }^{1}$ & Verwachting & Maximaal $^{1}$ \\
\hline 0 & & 29 & 0,09 & 6 & - & 0,00 \\
\hline 0,25 & & 9 & 0,04 & 6 & 0,05 & 0,25 \\
\hline 0,5 & & 4 & 0,02 & 6 & 0,06 & 0,50 \\
\hline 0,75 & & 2 & 0,01 & 6 & 0,07 & 0,75 \\
\hline 1 & & 1 & 0,01 & 5 & 0,08 & 1,00 \\
\hline 1,25 & & 1 & 0,01 & 5 & 0,08 & 1,25 \\
\hline 1,5 & & 1 & 0,01 & 5 & 0,08 & 1,50 \\
\hline 1,75 & & 0 & 0,01 & 5 & 0,08 & 1,75 \\
\hline 2 & & 0 & 0,00 & 4 & 0,08 & 2,00 \\
\hline 2,25 & & 0 & 0,00 & 4 & 0,08 & 2,25 \\
\hline 2,5 & & 0 & 0,00 & 4 & 0,08 & 2,50 \\
\hline 2,75 & & 0 & 0,00 & 4 & 0,08 & 2,75 \\
\hline 3 & & 0 & 0,00 & 3 & 0,08 & 3,00 \\
\hline 3,25 & & 0 & 0,00 & 3 & 0,08 & 3,25 \\
\hline 3,5 & & 0 & 0,00 & 3 & 0,08 & 3,50 \\
\hline 3,75 & & 0 & 0,00 & 3 & 0,08 & 3,75 \\
\hline 4 & & 0 & 0,00 & 2 & 0,08 & 4,00 \\
\hline 4,25 & & 0 & 0,00 & 2 & 0,08 & 4,25 \\
\hline 4,5 & & 0 & 0,00 & 2 & 0,08 & 4,50 \\
\hline 4,75 & & 0 & 0,00 & 2 & 0,08 & 4,75 \\
\hline
\end{tabular}

${ }^{1}$ Op basis van $10000 @$ risk iteraties.

Plafondbedrag sector (miljoen euro per 5 jaar)

Figuur B2.1 Relatie plafondbedrag en overheidsbijdrage per 5 jaar in de schapenhouderij, zowel in mln. euro (boven) als in \% (onder) 
Geitenhouderij

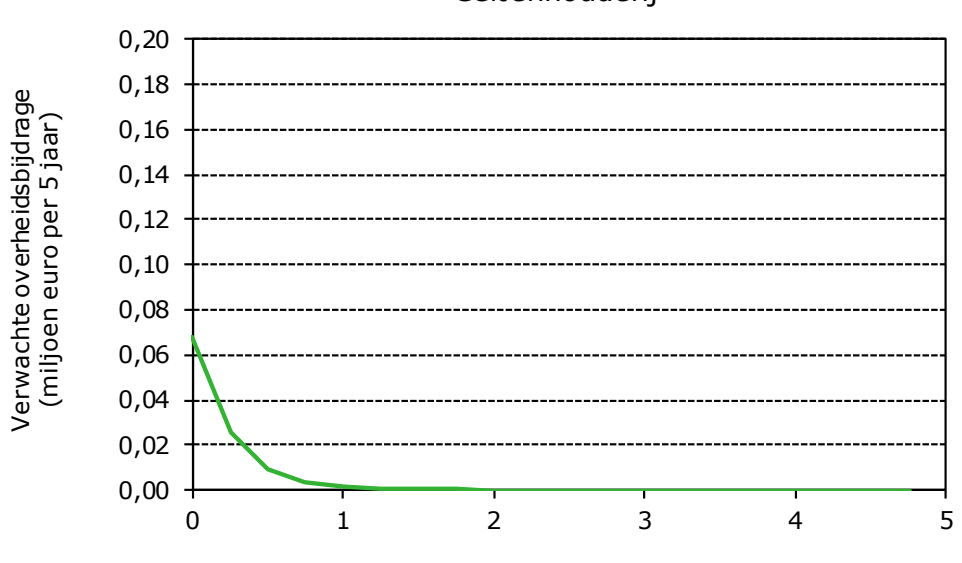

Plafondbedrag sector (miljoen euro per 5 jaar)

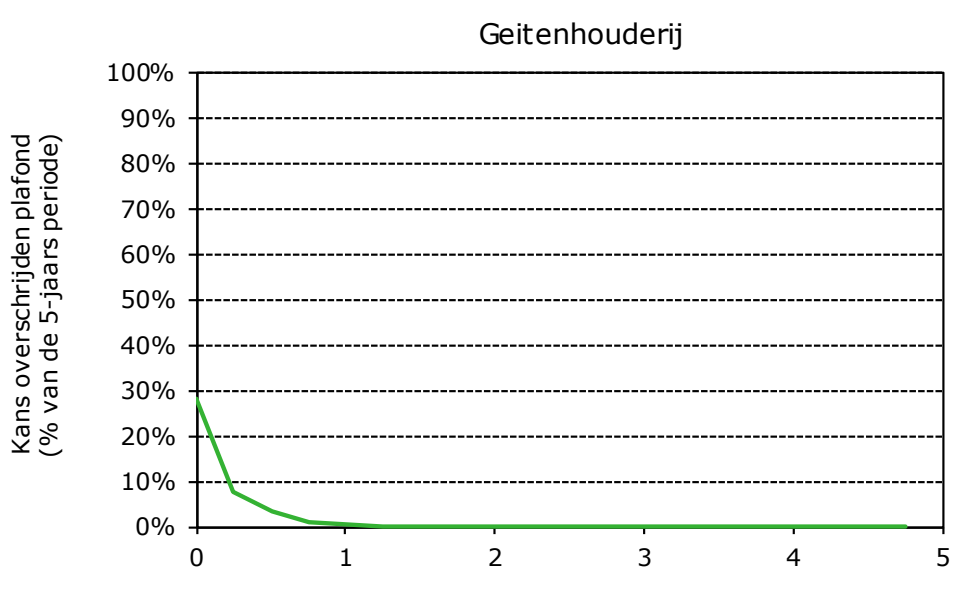

Plafondbedrag sector (miljoen euro per 5 jaar)
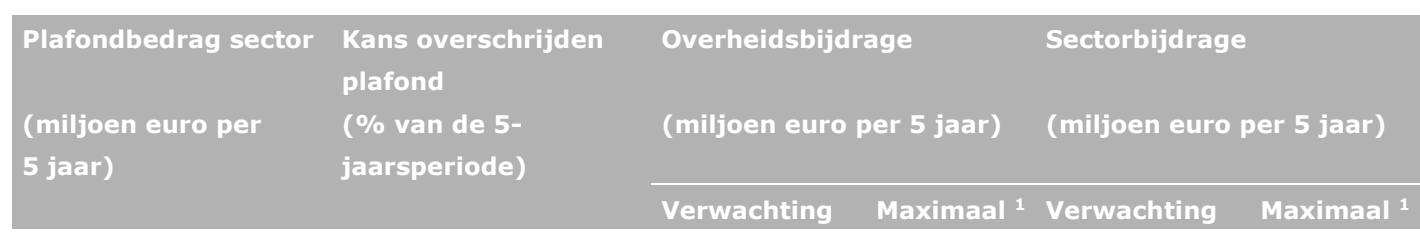

\begin{tabular}{rrrrrr}
0 & 28 & 0,07 & 2 & - & 0,00 \\
\hline 0,25 & 8 & 0,03 & 2 & 0,04 & 0,25 \\
\hline 0,5 & 3 & 0,01 & 2 & 0,06 & 0,50 \\
\hline 0,75 & 1 & 0,00 & 2 & 0,06 & 0,75 \\
\hline 1 & 1 & 0,00 & 1 & 0,07 & 1,00 \\
\hline 1,25 & 0 & 0,00 & 1 & 0,07 & 1,25 \\
\hline 1,5 & 0 & 0,00 & 1 & 0,07 & 1,50 \\
\hline 1,75 & 0 & 0,00 & 1 & 0,07 & 1,75 \\
\hline 2 & 0 & 0,00 & 0 & 0,07 & 2,00 \\
\hline 2,25 & 0 & 0,00 & 0 & 0,07 & 2,25 \\
\hline 2,5 & 0 & - & 0 & 0,07 & 2,50 \\
\hline 2,75 & 0 & - & 0 & 0,07 & 2,75 \\
\hline 3 & 0 & - & 0 & 0,07 & 3,00 \\
\hline 3,25 & 0 & - & 0 & 0,07 & 3,25 \\
\hline 3,5 & 0 & - & 0 & 0,07 & 3,50 \\
\hline 3,75 & 0 & - & 0 & 0,07 & 3,75 \\
\hline 4 & 0 & - & 0 & 0,07 & 4,00 \\
\hline 4,25 & 0 & - & 0 & 0,07 & 4,25 \\
\hline 4,5 & 0 & - & 0 & 0,07 & 4,50 \\
\hline 0 & 0 & - & 0 & 0,07 & 4,75 \\
\hline
\end{tabular}

${ }^{1}$ Op basis van 10000 @risk iteraties.

Figuur B2.2 Relatie plafondbedrag en overheidsbijdrage per 5 jaar in de geitenhouderij, zowel in mln. euro (boven) als in \% (onder) 
Wageningen Economic Research Postbus 29703

2502 LS Den Haag

T 0703358330

Ecommunications.ssg@wur.nl

www.wur.nl/economic-research

Wageningen Economic Research RAPPORT

2019-046
De missie van Wageningen University \& Research is 'To explore the potential of nature to improve the quality of life'. Binnen Wageningen University \& Research bundelen Wageningen University en gespecialiseerde onderzoeksinstituten van Stichting Wageningen Research hun krachten om bij te dragen aan de oplossing van belangrijke vragen in het domein van gezonde voeding en leefomgeving. Met ongeveer 30 vestigingen, 5.000 medewerkers en 10.000 studenten behoort Wageningen University \& Research wereldwijd tot de aansprekende kennisinstellingen binnen haar domein. De integrale benadering van de vraagstukken en de samenwerking tussen verschillende disciplines vormen het hart van de unieke Wageningen aanpak. 



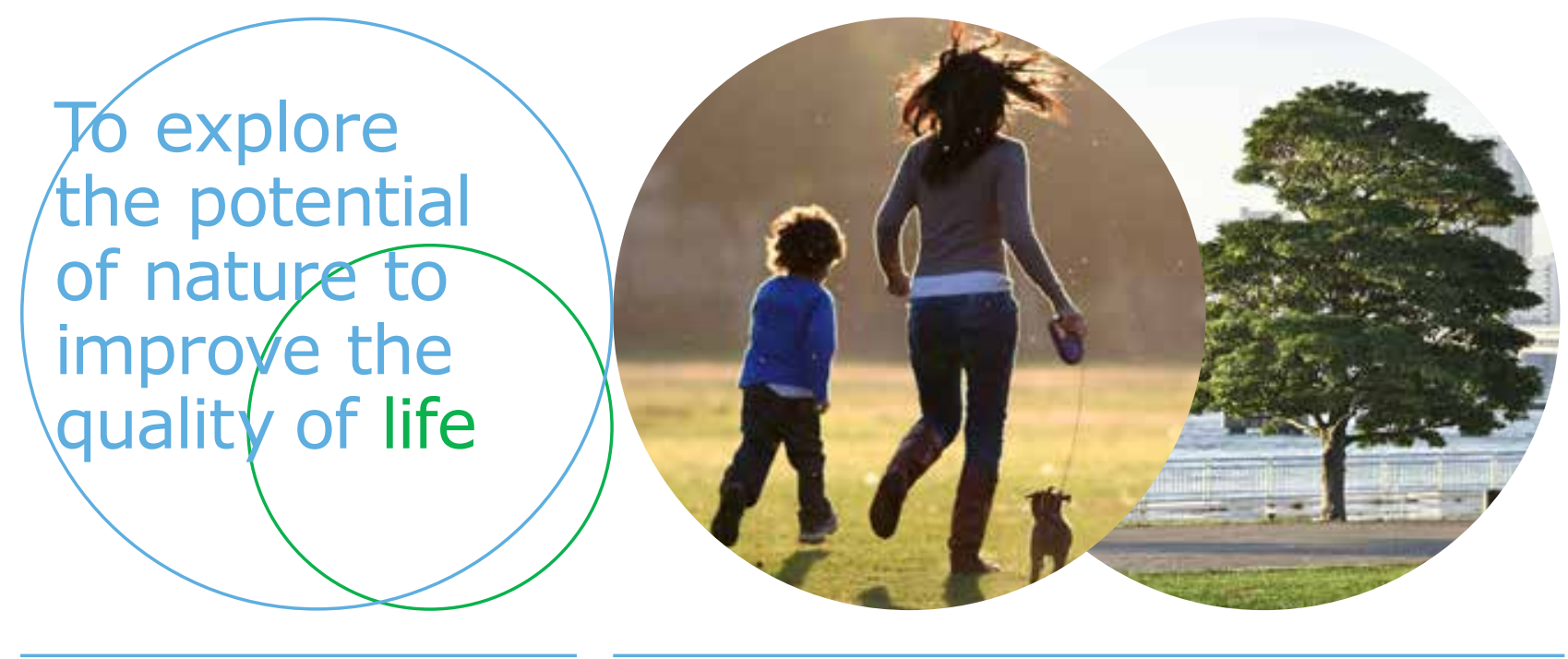

Wageningen Economic Research Postbus 29703

2502 LS Den Haag

E communications.ssg@wur.nl

$\mathrm{T}+31(0) 703358330$

www.wur.nl/economic-research

Rapport 2019-046

ISBN 978-94-6343-965-7
De missie van Wageningen University \& Research is 'To explore the potential of nature to improve the quality of life'. Binnen Wageningen University \& Research bundelen Wageningen University en gespecialiseerde onderzoeksinstituten van Stichting Wageningen Research hun krachten om bij te dragen aan de oplossing van belangrijke vragen in het domein van gezonde voeding en leefomgeving. Met ongeveer 30 vestigingen, 5.000 medewerkers en 10.000 studenten behoort Wageningen University \& Research wereldwijd tot de aansprekende kennisinstellingen binnen haar domein. De integrale benadering van de vraagstukken en de samenwerking tussen verschillende disciplines vormen het hart van de unieke Wageningen aanpak. 